\title{
A model for the evaluation of competence-based learning implementation in higher education institutions: Criteria and indicators
}

\author{
María José Bezanilla, Ana María García Olalla, \\ Jessica Paños Castro, and Manuel Poblete Ruiz*
}

doi: http://dx.doi.org/10.18543/tjhe-6(2)-2019pp127-174

Received: 11 April 2019

Accepted: 20 May 2019

\begin{abstract}
Almost twenty years after the Bologna Declaration was signed, the extent to which universities are embracing competence-based learning is a topic of much interest. This article presents a comprehensive model for the analysis of the implementation of competence-based learning (CBL) in Higher Education. An extensive bibliographic review was carried out on the concept of competence-based learning and on each of its constituent elements, with a view to proposing a model made up of seven dimensions and a set of evaluation criteria and indicators. The areas reviewed were the legal and administrative context, the institutional context, the degree programme planning process (including the individual modules/subjects within it), teaching practices and their assessment, and the review and improvement of the overall process. This explanatory model can be very useful to universities, particularly from Spain and Latin America, for assessing their level of implementation of competencebased learning, and identifying their strengths and areas for development.
\end{abstract}

* María José Bezanilla (marijose.bezanilla@deusto.es), PhD in Education from the Institute of Education, University of London (UK), is a tenured Lecturer at the Department of Innovation and Educational Organisation, University of Deusto (Spain).

Ana María García Olalla (ana.garciaolalla@deusto.es) is a tenured Lecturer at the Faculty of Psychology and Education at the University of Deusto (Spain) from which she obtained a PhD in Pedagogy.

Jessica Paños Castro (jessicapanos@deusto.es), PhD in Education student at the University of Deusto (Spain), holds a degree in Business Management and Administration and a Master's degree in Development and Management of Educational and Methodological Innovation projects in educational institutions.

Manuel Poblete Ruiz (manuel.poblete@deusto.es), Professor Emeritus at the University of Deusto (Spain), has a PhD in Psychology at the University of Barcelona (Spain). In the last twelve years, he has participated as a coordinator and as a member of several research projects on competence development and teaching innovation.

More information about the authors is available at the end of this article. 
Keywords: Competence-based learning; generic competences; higher education; evaluation model; teaching innovation.

\section{Introduction}

In the late twentieth century, the various changes that occurred in society and in the world of work demanded shifting from a culture based on qualifications and specialisation to one of professional competence and multifunctionality. Delors ${ }^{1}$ summarised the guidelines for teaching innovation, which should be aimed at learning to know, learning to do, learning to live together and learning to be, a vision that should guide future reforms in relation both to programmes and to methods. While this approach had been partially implemented in English-speaking countries, it was translated into CompetenceBased Learning (CBL) in Europe.

Much has been written about CBL since then. Studies have fundamentally relied on an approach to the teaching-learning process that has sought to provide students with an educational foundation to meet society's needs in work, civic, professional and ethical terms. Some pieces of research have focused on the concept itself; others, on the importance of defining competences; some others, on the importance of distinguishing between specific and general competences; other studies have been centred on whether CBL can be taught and learnt; whereas some have dealt with competence-based teaching and assessment methodologies. ${ }^{2}$ Álvarez ${ }^{3}$ conducted a review of research conducted on generic competences over the past fifteen years. According to his data, the research concerns innovation experiences and their outcomes, training, competence assessment, conceptual frameworks, and regulations on competences.

Following the Bologna Declaration, ${ }^{4}$ the Bologna Process raised the importance of focusing EU efforts on the design and implementation of Higher Education degree programmes using a competence-based approach. It involved actors at different decision-making levels, including national education

1 Jacques Delors, coord., La educación encierra un tesoro. Informe a la UNESCO de la Comisión Internacional sobre la educación para el siglo XXI (París: UNESCO - Santillana, 1998).

2 Verónica Villarroel and Daniela Bruna, "Reflexiones en torno a las competencias genéricas en educación superior: Un desafío pendiente," Psicoperspectivas 13, no. 1 (2014): 23-34.

${ }^{3}$ Pedro Ricardo Álvarez, Competencias genéricas en la enseñanza universitaria. De la tutoría formativa a la integración curricular (Málaga: Aljibe, 2016).

4 "Bologna Declaration," 1999, http://www.ehea.info/media.ehea.info/file/Ministerial_ conferences/02/8/1999_Bologna_Declaration_English_553028.pdf. 
authorities, university and student associations, and Higher Education institutions (HEIs). Various follow-up meetings were held, and some activities were carried out conducive to the implementation of the goals and objectives proposed. They resulted in a number of stocktaking reports for the whole of the EU and for each member state. ${ }^{5}$ Out of the thirteen indicators currently used, two of them are linked to the object of study here: the use of credits as tools that reflect student workload (ECTS system) and the development of a framework of qualifications in the signatory countries. Both the Dublin Descriptors and the subsequent Framework for Qualifications of the European Higher Education Area $^{6}$ as well as the European Qualification Framework for Life-long-learning ${ }^{7}$ are structured in terms of competences and learning outcomes.

Some international organisations have supported and funded projects such as $\mathrm{DeSeCo}^{8}$ and Tuning, ${ }^{9}$ among others, in order to improve the level of achievement of the objectives set in the Bologna Declaration. ${ }^{10}$ The Tuning Project (intercultural university cooperation project) has bolstered one of the main initiatives to apply CBL in HEIs, which started in Europe and was later extended to Latin America, ${ }_{11}^{11}$ Asia, and Africa. CBL is described by Villa and Poblete as:

CBL consist in developing necessary generic or transversal (instrumental, interpersonal and systemic) competences and the specific competences pertaining to each profession. The aim is to endow students with scientific and technical knowledge, and enable them to apply such knowledge in diverse complex contexts. To this end, knowledge is integrated along with

5 European Commission/EACEA/Eurydice, The European Higher Education Area in 2015: Implementation Report (Luxembourg: Publications Office of the European Union, 2015).

${ }^{6}$ Bologna Working Group on Qualifications Frameworks, A Framework for Qualifications of the European Higher Education Area (Copenhaguen: Ministry of Science, Technology and Innovation, 2005, http://ecahe.eu/w/images/7/76/A_Framework_for_Qualifications_for_the_ European_Higher_Education_Area.pdf

${ }^{7}$ European Commission, The European Qualifications Framework for Lifelong Learning (EQF) (Luxembourg: Publications Office of the European Union, 2008).

${ }^{8}$ OECD, La Definición y Selección de Competencias clave (DESECO). Resumen ejecutivo, 2005, http://comclave.educarex.es/pluginfile.php/130/mod_resource/content/3/ DESECO.pdf.

9 Julia González and Robert Wagenaar, Tuning Educational Structures in Europe. Final Report - Phase 1(Bilbao: Universidad de Deusto, 2003.

10 "Bologna Declaration," 1999, http://www.ehea.info/media.ehea.info/file/Ministerial_ conferences/02/8/1999_Bologna_Declaration_English_553028.pdf.

${ }^{11}$ Pablo Beneitone, César Esquetini, Julia González, Maira Maletá, Gabriela Siufi, and Robert Wagenaar, eds., Reflexiones y perspectivas de la educación superior en América latina. Informe Final - Proyecto Tuning - América Latina, 2004/2007 (Bilbao and Groningen: University of Deusto, 2008). 
attitudes and values in ways that are appropriate for each student's personal and professional life. ${ }^{12}$

The relevant EU and national bodies, education authorities and quality assurance agencies have put in place frameworks and procedures in order to implement and promote these guidelines. The ENQA ${ }^{13,14}$ has developed two versions of 'Standards and Guidelines for Quality Assurance in the European Higher Education Area (EHEA)'. The first version ${ }^{15}$ included three of the seven standards which refer to the issue at stake. Standards 1 and 2 concern the need that institutions should have a policy and associated procedures for the assurance of the quality of their awards. Standard 3 establishes that students should be evaluated according to standards, regulations and procedures that are public and coherent, ensuring they are designed to measure learning outcomes; fit for purpose; and based on explicit and published criteria. The revised version of this framework ${ }^{16}$ contains three (out of ten) standards that are focused on this matter: design and approval of programmes (standard 2); monitoring and review of programmes (standard 9); and ensuring programmes promote student-centred learning, teaching and assessment (standard 3).

At a national level, education ministries and quality assurance agencies have developed regulations and programmes that have set out procedures and standards for the design, approval, monitoring and assessment of their qualifications. Higher Education regulations in Spain $^{17}$ have established a number of learning goals formulated in terms of competences that are the backbone of their qualifications. Both the guidelines for the design and

12 Aurelio Villa and Manuel Poblete, Competence-based learning. A proposal for the assessment of generic competences (Bilbao: University of Deusto, 2009), 33.

${ }_{13}$ ENQA, Standards and guidelines for Quality Assurance in European Higher Education Area (Helsinki: ENQA, 2005), http://www.enqa.net/bologna.lasso. ESTE ENLACE NO FUNCIONA.

${ }^{14}$ ENQA, Standards and guidelines for Quality Assurance in European Higher Education Area (Brussels, Belgium, 2015), http://www .enqa.eu/index.php/home/esg/.

${ }^{15}$ ENQA, Standards and guidelines for Quality Assurance in European Higher Education Area (Helsinki: ENQA, 2005), http://www .enqa.net/bologna.lasso.

${ }^{16}$ ENQA, Standards and guidelines for Quality Assurance in European Higher Education Area (Brussels, Belgium, 2015), http://www .enqa.eu/index.php/home/esg/.

17 MEC, Real Decreto 1393/2007, de 29 de octubre, por el que se establece la ordenación de las enseñanzas universitarias oficiales, 2007, https://www.boe.es/boe/dias/2007/10/30/pdfs. 
approval of qualifications, ${ }^{18,19}$ and for the monitoring and accreditation reviews ${ }^{20}$ provide criteria as to how those competences should be formulated and aligned with teaching and assessment methodologies.

While there is extensive literature on CBL, no single model exists to investigate to what extent it has been implemented in a given university, institution or qualification. Several authors have noted the need to have standards and tools to this effect, to help institutions and their managers to face the process, beyond the important role played by lecturers and students. ${ }^{21,22,23,24}$ A series of studies have proposed models related to competence-based curriculum design,,$^{25,26,27,28}$ whereas others have put forward strategic

18 ANECA, "Guía de Apoyo para la redacción, puesta en práctica y evaluación de los Resultados del Aprendizaje," 2015, http://www.aneca.es/content/download/12155/136031/ file/verifica_gm_guia_V05.pdf.

19 REACU, Protocolo de evaluación para la verificación de títulos universitarios oficiales, 2011, http://www.aneca.es/content/download/12387/153627/file/verifica_protocolo_ gradomaster_110207.pdf.

20 ANECA, "Documento Marco: Evaluación para la renovación de la acreditación de títulos oficiales de Grado, Máster y Doctorado," 2016, http://www.aneca.es/content/ download/12737/157930/file/acredita_documentomarco_v4b.pdf.

${ }^{21}$ Peter Harris, Linda Snell, Martin Talbot, Ronald Harden, and international CBME collaborators, "Competency-based medical education: implications for undergraduate programs," Medical Teacher 32, no 8 (2010): 646-650.

${ }_{22}$ Vasanti Lagali-Jirge, "Need for paradigm shift in Indian dental education: A case for change toward competency-based education," Journal of Indian Academy of Oral Medicine and Radiology 27, no 2) (2015): 230-236.

${ }^{23}$ Daniela Drago, Sandra Shire, and Ozgur Ekmekci, "Improving Regulatory Education: Can We Reconcile Employers' Expectations With Academic Offerings?," Therapeutic Innovation \& Regulatory Science 50, no 3 (2016): 330-336.

${ }^{24}$ Larry Gruppen, John Burkhardt, James Fitzgerald, Martha Funnell, Hilary Haftel, Monica Lypson, and John Vasquez, "Competency based education: programme design and challenges to implementation," Medical education 50, no. 5 (2016): 532-539.

25 Rodolfo Schmal and Andrés Ruiz-Tagle, "Una metodología para el diseño de un currículo orientado a las competencias. Ingeniare," Revista chilena de ingenierí 16, no. 1 (2008): 147-158.

${ }^{26}$ Rodolfo Schmal and Andrés Ruiz-Tagle, "Una metodología para el diseño de un currículo orientado a las competencias," Revista electrónica de desarrollo de competencias 2 , no. 4 (2009): 1-21.

${ }^{27}$ Martin Durán-García and Emilse Durán-AponteEmpresa, "Universidad y competencias. Propuesta de un modelo sistémico,” Revista Gestión Universitaria 3, no. 3 (2011).

${ }^{28}$ Gabriel Icarte and Hugo Lávate, "Metodología para la Revisión y Actualización de un Diseño Curricular de una Carrera Universitaria Incorporando Conceptos de Aprendizaje Basado en Competencias," Formación Universitaria 9, no. 2 (2016): 3-16. 
educational management models..$^{29,30}$ But none of them have developed a comprehensive model with criteria and indicators to analyse the degree of implementation of CBL in a given HEI or qualification. ${ }^{31}$

Two decades after this process began, it is time to take stock of its impact and analyse to what extent CBL has been implemented in HEIs. This process should take into account the most significant factors highlighted in the literature, which the promoting bodies and the stakeholders have attempted to adapt and transform over time.

\section{Objectives}

This paper seeks to answer the following research question: what are the key dimensions in the implementation of CBL in a HEI, and how can these dimensions be reflected in terms of criteria and indicators?

The aim is to provide a model to assess the extent to which CBL has been implemented, and to provide elements to identify the focus areas needed to further its development, by disaggregating them into dimensions, criteria and indicators. This model not only takes into account institutional aspects, but also those related to the legal and administrative context involved.

\section{Methodology}

This study uses qualitative methodology and is based on a systematic documentary review. It is exploratory in scope, since it is aimed at examining a little-researched area. ${ }^{32}$ The first step was to carry out a literature review of existing models for the evaluation of $\mathrm{CBL}$, using the meta-search engine Océano, a tool for searching bibliographic data that includes more than one hundred impact databases, both national and international, where scientific

${ }^{29}$ Rodolfo Schmal and Andrés Ruiz-Tagle, "Un modelo para la gestión de una escuela universitaria orientada a la formación basada en competencias," Cuadernos de Administración 22, no. 39 (2009): 287-305.

30 Analia Giménez, "El papel de la gestión de centros educativos en un modelo de aprendizaje basado en competencias," Páginas de Educación 9, no. 1 (2016): 5-15.

${ }_{31}$ Amie Dragoo and Richard Barrows, "Implementing Competency-Based Education: Challenges, Strategies, and a Decision-Making Framework," The Journal of Continuing Higher Education 64, no. 2 (2016): 73-83.

32 Robert Hernández, Carlos Fernández, and Pilar Baptista, Metodología de la investigación (México: McGraw Hill, 2014). 
papers, books, official documents, $\mathrm{PhD}$ theses and work submitted to conferences were consulted. The search descriptors were first constrained to 'competence-based learning', which yielded 395 results (out of which 67 referred to Higher Education), and to its Spanish equivalent ('aprendizaje basado en competencias'), which yielded 77 results (out of which 13 referred to Higher Education). Since the term 'competence' is often known as 'skill' in the Anglo-Saxon world and is related to generic or transversal competences, an open search was also conducted. The search phrase was 'model key transversal soft generic skills in higher education', and the search yielded 219 results, 67 of them from peer-reviewed journals. These two searches returned 38 results, which to some extent were related to learning/assessment competence-based 'models', but not necessarily to the evaluation of how CBL had been implemented. The models employed to analyse CBL included the proposals made by Cardoso, Tavares and Sin; ${ }^{33}$ Acebedo-Afanador, Aznar-Díaz, and Hinojo-Lucena; ${ }^{34}$ Poblete, Bezanilla, Fernández-Nogueira and Campos; ${ }^{35}$ Villa, Campo, Villa, García-Olalla and Arranz; ${ }^{36}$ Icarte and Lávate ${ }^{37}$ Villa,

${ }^{33}$ Sonia Cardoso, Orlanda Tavares, and Cristina Sin, "The quality of teaching staff: higher education institutions' compliance with the European Standards and Guidelines for Quality Assurance - the case of Portugal," Educational Assessment, Evaluation and Accountability 27, no. 3 (2015): 205-222.

${ }^{34}$ Manuel José Acebedo-Afanador, Inmaculada Aznar-Díaz, and Francisco Javier Hinojo-Lucena, "Instrumentos para la evaluación del aprendizaje basado en competencias: Estudio de caso," Información Tecnológica 28, no. 3 (2017): 107-118.

${ }_{35}$ Manuel Poblete, María José Bezanilla, Donna Fernández, and Lucía Campo, "Formación del docente en competencias genéricas: un instrumento para su planificación y desarrollo," Educar 52, 1 (2016): 71-91.

${ }^{36}$ Aurelio Villa, Lucía Campo, Olga Villa, Ana García-Olalla, and Sonia Arranz, "Valoración del profesorado de magisterio sobre el aprendizaje basado en competencias implantado," Profesorado. Revista de curriculum y formación del profesorado 17, no. 3 (2013): 35-55.

${ }^{37}$ Gabriel Icarte and Hugo Lávate, "Metodología para la Revisión y Actualización de un Diseño Curricular de una Carrera Universitaria Incorporando Conceptos de Aprendizaje Basado en Competencias," Formación Universitaria 9, no. 2 (2016): 3-16. 
Arranz, Campo and Villa; ${ }^{38} \mathrm{Ku}$ Mota and Tejada; ${ }^{39}$ Rueda; ${ }^{40}$ García; $;{ }^{41}$ and García. ${ }^{42}$ However, most of them presented either partial or broad models, and did not provide detailed indicators or descriptors. It calls attention that the majority of these models are published in Spanish language, since perhaps it is in Spanish speaking countries where CBL has had more incidence and impact.

Based on the literature reviewed, of both the ten systematic models encountered and of the partial contributions made by other authors, a model for the evaluation of CBL implementation was designed. This model was later submitted to the assessment of eight experts, ${ }^{43}$ to ensure its reliability, validity, pertinence and usefulness. ${ }^{44}$ The experts assessed the degree of consistency, clarity and relevance, and also noted whether it was necessary to add, delete and/or reformulate some items ${ }^{45}$ namely aspects, criteria and/or indicators subject to evaluation. The demand for quality followed ensured the existence of a unanimous positive evaluation by the 8 experts, for the inclusion of the criteria and indicators in the model. The initial design of the model had 28 criteria and 132 indicators. After a review process carried out during the course of 9 meetings among experts over an entire academic year, the model was finally structured into 18 criteria and 96 indicators.

38 Aurelio Villa, Sonia Arranz, Lucía Campo, and Olga Villa, "Percepción del profesorado y responsables académicos sobre el proceso de implantación del Espacio Europeo de Educación Superior en diversas titulaciones de educación," Profesorado. Revista de curriculum y formación del profesorado 19, no. 2 (2015): 245-264.

39 María Magdalena Ku Mota and José Tejada, Diagnóstico de necesidades basadas en competencia del profesorado de los institutos Tecnológicos de Quintana Roo, México (Barcelona: Universitat Autònoma De Barcelona, Departament De Pedagogia Aplicada, 2013).

${ }^{40}$ Mario Rueda, "La evaluación del desempeño docente: consideraciones desde el enfoque por competencias," Revista Electrónica de Investigación Educativa 11, no. 2 (2009): 1-16.

${ }^{41}$ María Pilar García, "Estatus actual del profesorado en la educación superior: revisión de conceptos y modelos competenciales," Tonos Digital 30 (2016): 1-21.

${ }^{42}$ María José García, Evaluar la integración de las competencias en la universidad (Bilbao: Mensajero, 2013).

${ }^{43}$ University lecturers and professors from Spain and Latin America with a track record as researchers and managers, including the monitoring and evaluation of qualifications, the development of generic competences, teaching evaluation and quality assurance, and Tuning project members.

${ }_{44}$ Thomas Knapp and Ralph Mueller, "Reliability and validity of instruments," in The reviewer guide to quantitative methods in the social science, ed. Gregory Hancock and Ralph Mueller (New York: Routledge, 2010), 337-341.

${ }^{45}$ Rafael Bisquerra, Metodología de la investigación educativa (Madrid: La Muralla, 2009). 


\section{The Model}

The model has seven dimensions, which explore the degree of implementation of CBL in HEIs (see Figure 1). The CIPP model was deemed the most appropriate to use, as it is a model for the evaluation of an institution..$^{46,47}$ We used an approach similar to this model which aims at evaluating a programme at HEI level in order to support decision-making for improvement. It is focused on the evaluation of dimensions and indicators referred to context (C), inputs (I), process $(\mathrm{P})$, and products $(\mathrm{P})$. The model proposed here provides two dimensions that review the contextual aspects of CBL implementation. This includes a national regulatory framework, and a more restrictive HEI regulatory framework. Three dimensions describe the implementation process within the institution, with regard to the design of degree qualifications, the subject/module planning process and teaching/learning practices. It also proposes using two dimensions that analyse the outcomes obtained and review the degree and subject/module programme planning.

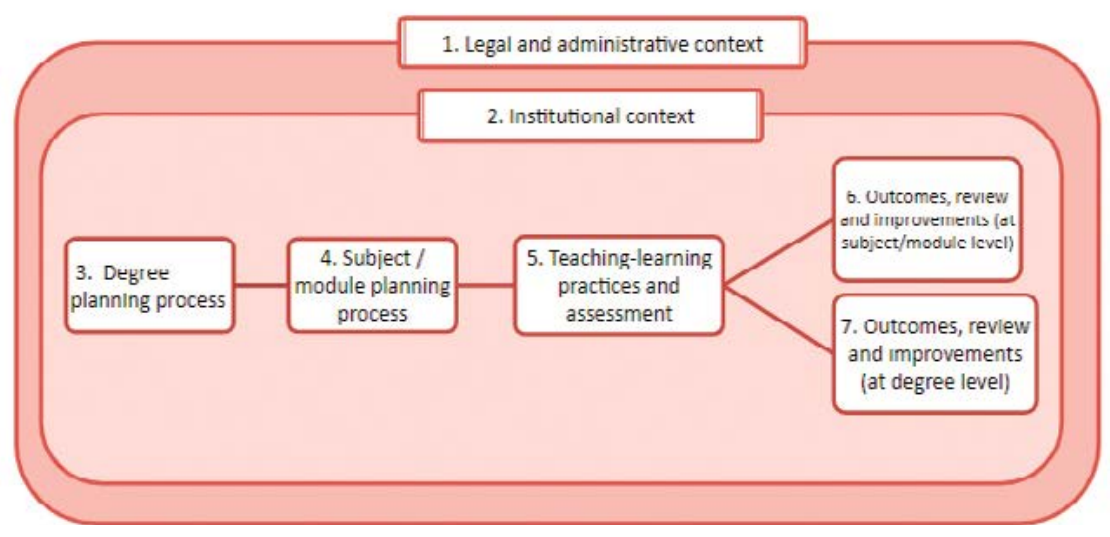

Figure 1.

Dimensions of a CBL model

${ }^{46}$ Daniel Stufflebeam, "The CIPP Model for program evaluation," in Evaluation models, ed. George Madaur, M. Scriven and Daniel Stufflebeam (Boston: Kluwer-Nijhoff, 1983).

${ }^{47}$ Daniel Stufflebeam and Anthony Shinkfield, Evaluation theory, models and applications (San Francisco: Jossey-Bass, 2007). 
The criteria and indicators are the means for determining what and how to evaluate, by establishing the positive, desirable qualities and characteristics within the dimensions under review. However, they have a different degree of specificity. Criterion here means a pre-established requirement or quality standard used to evaluate a system, a programme or an object of assessment. A criterion usually describes an overall, more or less observable situation, and therefore requires other means to make it more concrete, namely indicators. Indicators are instruments that provide relevant information about a significant aspect of an educational or institutional situation, that is, systematically collected quantitative or qualitative empirical pieces of data used to make an assessment. They are then used as the basis for improvements. The degree of compliance with the various indicators for each dimension should be evaluated according to the evidence obtained through different techniques and activities.

\subsection{Dimension 1: legal and administrative context}

Every country and region has a legislative context within which university activities must operate. On some occasions, the legal framework has encouraged innovation and a change of paradigm from instruction to learning, whereas in some countries very open provisions have been established that have allowed HEIs plenty of room for manoeuvre. Countries that have passed laws and regulations to guide this change and set out appropriate requirements have predictably seen more noticeable steps being taken, such as EU countries after the Bologna Declaration. ${ }^{48}$ The applicable Higher Education laws in several Latin American countries (Chile, Mexico, Argentina, Ecuador, the Dominican Republic, Colombia, Venezuela and Peru) and Spain $^{49}$ have been reviewed to determine which of their guidelines are related to the object of study in this paper. Four types of guidelines were identified, which have been reformulated in terms of criteria.

48 Bologna Declaration, 1999, http://www.ehea.info/media.ehea.info/file/Ministerial_ conferences/02/8/1999_Bologna_Declaration_English_553028.pdf.

${ }^{49}$ General Education Law (Chile) 20370 (2009); Education Law in the State of Nuevo León. Latest Reform (2014); Organic Law on Higher Education (Ecuador) (2010); General Education Law (Colombia) 18437 (2009); General Education Law (Peru) 28044 (2003); General Education Law (Mexico) (1993; latest reform 2017); National Education Law (Argentina) 26206 (2006); Organic Law on Education (Venezuela) (2009); Law 139-01 on Higher Education, Science and Technology (Dominican Republic) (2001); Organic Law 6/2001, of 21 December, on Universities (Spain); Royal Decree 1393/2007, of 29 October, which governs official university education (ANECA 2013; 2015a, 2016; REACU, 2011). 
The first criterion was the existence of legislation that promotes a process of innovation in Higher Education and incorporates CBL. Explicit promotion of competence-based education was rare (only in Spain), whereas provisions on a student-centred approach were found in the laws of some countries (Mexico, Spain), and university autonomy was recognised across the board (Ecuador, Colombia, Mexico, Peru, Chile, Spain). A Higher Education system structured into stages in terms of Undergraduate Degree, Master's Degree, and Doctorate was generally recognised as well (Ecuador, Chile, Mexico, Colombia, Spain). References to the need for teaching staff to work on a collegial basis were rarely found.

The second criterion was that laws provide guidance on how to design a competence-based degree qualification. Having reviewed the references made to this kind of degree organisation in the different legal systems mentioned above, the main aspects identified were: the formulation of objectives as competences (Spain); an explicit difference made between (specific) competences sought in the various degrees, and (generic or transversal) competences, which were more personal in nature; a change in the methodology, marked by student-centred teaching-learning processes (Mexico, Spain); and student work time being taken into account (Mexico, Colombia, Spain, Venezuela); whereas learning assessment based on the defined competences was found to be less frequent (only in Spain).

The third criterion referred to the procedures put in place by HEIs to internally monitor degrees (Spain); and to external mechanisms to obtain official accreditation from education authorities or delegated agencies which include references to CBL (Mexico, Colombia, Peru, Chile, Ecuador, Spain).

The fourth criterion to verify the level of commitment to CBL in a given country was governmental support, as evidenced by specific funding, resources and other incentives for training and/or innovation projects and teaching improvement for CBL (Mexico, Ecuador, Colombia, Peru, Chile, and Spain). See table 1.

\subsection{Dimension 2: institutional context}

This process involves changes in how universities are structured. One of the first steps should be adapting their mission, vision and strategic plan to incorporate $\mathrm{CBL},{ }^{50}$ and to make them consistent with the university's

${ }_{50}$ Aurelio Villa and Manuel Poblete, Competence-based learning. A proposal for the assessment of generic competences (Bilbao: University of Deusto, 2009). 
educational policy. A university-specific learning $\operatorname{model}^{51}$ is also needed to provide students with a sense of identity. ${ }^{52}$ Some universities have defined identity-based competences, to be acquired by all students in the performance of any profession and in their life.$^{53,54}$ According to the recommendations made by ANECA,${ }^{55}$ these documents should be readily accessible on university websites to ensure transparency and allow stakeholders to make decisions.

These changes have been possible thanks to: the commitment made by the universities' management teams, including the Chancellor and Vicechancellor's offices $;{ }^{56}$ the creation of advisory and training units that support individual and institutional demands, ${ }^{57,58}$ the introduction of pedagogical coordinators for each degree, year or area of knowledge ${ }^{59}$ and the support provided by administrative services. ${ }^{60}$

In Spain, the guidelines for the design of degree qualifications ${ }^{61}$ establish that the curriculum should include the generic and specific competences to be

${ }^{51}$ Manuel Poblete, "Evaluación de competencias en la Educación Superior: dificultades y condiciones," IV Jornadas Universitarias de Innovación y Calidad Bilbao: Universidad de Deusto, 2008.

${ }^{52}$ MEC, Propuesta para la Renovación de las metodologías educativas en la universidad (Madrid: MEC, Secretaría de Estado de Universidades, 2006), https://sede.educacion.gob.es/ publiventa/descarga.action?f_codigo_agc=12114_19.

${ }_{53}$ Alejandro Sepúlveda, Margaly Andrea Quintana, Margarita Opazo, Rodolfo Lemarie, and Daniel Sáez, "Nivel de promoción de competencias genéricas-sello institucionales en Educación Básica, parvularia y diferencial: percepción de los estudiantes," Revista de Orientación Educacional 27, no. 52 (2013): 75-87.

${ }^{54}$ Julia González and Robert Wagenaar, Tuning Educational Structures in Europe. Final Report - Phase 1 (Bilbao: Universidad de Deusto, 2003.

55 ANECA, "Documento Marco: Evaluación para la renovación de la acreditación de títulos oficiales de Grado, Máster y Doctorado," 2016, http://www.aneca.es/content/ download/12737/157930/file/acredita_documentomarco_v4b.pdf

${ }^{56}$ Aurelio Villa and Manuel Poblete, Competence-based learning. A proposal for the assessment of generic competences (Bilbao: University of Deusto, 2009).

${ }^{57}$ MEC, Propuesta para la Renovación de las metodologías educativas en la universidad (Madrid: MEC, Secretaría de Estado de Universidades, 2006), https://sede.educacion.gob.es/ publiventa/descarga.action?f_codigo_agc=12114_19.

58 Antonio Calvo-Bernardino and Ana Cristina Mingorance-Arnáiz, "La estrategia de las universidades frente al Espacio Europeo de Educación Superior," Revista Complutense de Educación 20, no. 2 (2009): 319-342.

59 Antonio Calvo-Bernardino and Ana Cristina Mingorance-Arnáiz, "La estrategia de las universidades frente al Espacio Europeo de Educación Superior," Revista Complutense de Educación 20, no. 2 (2009): 319-342.

${ }^{60}$ Aurelio Villa and Manuel Poblete, Competence-based learning. A proposal for the assessment of generic competences (Bilbao: University of Deusto, 2009).

${ }_{61}$ ANECA, "Guía de Apoyo para la elaboración de la Memoria de verificación de Títulos Oficiales Universitarios,” 2015, http://www .aneca.es/content/download/12155/136031/file/ 
acquired by students to successfully complete their degree. They also provide that faculty members must prepare teaching guides with a module plan focused on the acquisition of those competences. ${ }^{62}$ Evidence has been found that there is a need for institutions to incorporate mechanisms to design, approve, monitor and review their qualifications and teaching guides.

The criteria set out by ENQA ${ }^{63,64}$ require that the teaching staff must be appropriately qualified and must have the opportunity to acquire their own competences as necessary, as part of the internal quality assurance system for which each institution is responsible. The programmes developed by ANECA ${ }^{65}$ include the assessment and accreditation of the faculty. This agency is in charge of evaluating the qualifications needed to hold teaching positions or be part of the teaching staff; whereas universities should have criteria for their internal selection process, take responsibility for assessing their personnel, identify any training needs, design actions to correct the deficiencies detected, ${ }^{66}$ and provide some tools and resources to help implement initiatives for teaching innovation and improvement. See table 2.

\subsection{Dimension 3: Degree programme planning process}

It has been a regular practice in Higher Education planning processes to consider the curriculum to be the sum of the individual modules (or similar units) that constitute it, and therefore to have each individual module organised separately. Since competences are ambitious, integrative learning objectives to

verifica_gm_guia_V05.pdf.

${ }^{62}$ Antonio Calvo-Bernardino and Ana Cristina Mingorance-Arnáiz, "La estrategia de las universidades frente al Espacio Europeo de Educación Superior," Revista Complutense de Educación 20, no. 2 (2009): 319-342.

${ }^{63}$ ENQA, Standards and guidelines for Quality Assurance in European Higher Education Area (Helsinki: ENQA, 2005), http://www.enqa.net/bologna.lasso.

${ }^{64}$ ENQA, Standards and guidelines for Quality Assurance in European Higher Education Area (Brussels, Belgium, 2015), http://www.enqa.eu/index.php/home/esg/.

${ }^{65}$ ANECA, "Programa DOCENTIA (Programa de apoyo para la evaluación de la actividad docente del profesorado universitario). Integración y actualización de la documentación delPrograma,"2015.v1,http://www.aneca.es/content/download/13305/164819/ file/DOCENTIA_nuevadoc_v1_final.pdf.

${ }^{66}$ Susana Arànega, De la detección de las necesidades de formación pedagógica a la elaboración de un plan de formación en la sociedad (Barcelona: Octaedro, 2013). 
be achieved, ${ }^{67,68,69}$ it became apparent that implementing CBL would not be feasible on an individual module basis. It was seen that it would be necessary to engage in collegial efforts to organise how the competences are progressively acquired throughout the whole curriculum. ${ }^{70,71,72}$ This new collegial approach, which can be brought about through different structures and/or roles, has come to be essential.

The first requirement for designing a competence-based degree programme is the existence of an integrated educational project. The professionalisation of the Higher Education curriculum and the growing demand for socially responsible professional performance ${ }^{73,74}$ has emphasised the need to analyse the environment, in order to ensure the pertinence and focus the direction of degree programmes, ${ }^{75,76}$ and to define a professional profile to work towards. ${ }^{77}$

${ }^{67}$ Bologna Declaration, 1999, http://www.ehea.info/media.ehea.info/file/Ministerial_ conferences/02/8/1999_Bologna_Declaration_English_553028.pdf.

${ }_{68}$ Bologna Working Group on Qualifications Frameworks, A Framework for Qualifications of the European Higher Education Area (Copenhaguen: Ministry of Science, Technology and Innovation, 2005), http://ecahe.eu/w/images/7/76/A_Framework_for_ Qualifications_for_the_European_Higher_Education_Area.pdf.

${ }^{69}$ European Comission, The European Qualifications Framework for Lifelong Learning $(E Q F)$ (Luxembourg: Publications Office of the European Union, 2008).

${ }^{70}$ Mario de Miguel et al., Adaptación de los planes de estudio al proceso de Convergencia europea (Madrid: Dirección General de Universidades, MEC - Programa de Estudios y Análisis para la mejora de la calidad de la enseñanza y de la actividad del profesorado universitario, 2004).

${ }^{71}$ Rosa María Rodríguez, "Mejora continua de la práctica docente universitaria: una experiencia desde el proceso de convergencia del EEES," Revista Electrónica Interuniversitaria de Formación del Profesorado 10, no. 1 (2007): 1-8.

${ }^{72}$ Francisco Javier Tejedor and Ana García-Valcárcel, "Causas del bajo rendimiento del estudiante universitario (en opinión de los profesores y alumnos). Propuesta de mejora en el marco del EEES," Revista de Educación 342 (2007): 443- 472.

${ }^{73}$ Jacques Delors, coord., La educación encierra un tesoro. Informe a la UNESCO de la Comisión Internacional sobre la educación para el siglo XXI (París: UNESCO - Santillana, 1998).

${ }^{74}$ José Bricall, Universidad 2000 (Madrid: CRUE, 2000).

75 Julia González and Robert Wagenaar, eds., Tuning educational Structures in Europe. Universities contribution to the Bologna Process. Final Report. Pilot Project - Phase 2 (Bilbao: University of Deusto and University of Groningen, 2006).

${ }^{76}$ ANECA, "Guía de Apoyo para la elaboración de la Memoria de verificación de Títulos Oficiales Universitarios," 2015, http://www .aneca.es/content/download/12155/136031/file/ verifica_gm_guia_V05.pdf.

77 Mario de Miguel et al., Adaptación de los planes de estudio al proceso de Convergencia europea (Madrid: Dirección General de Universidades, MEC - Programa de Estudios y Análisis para la mejora de la calidad de la enseñanza y de la actividad del profesorado universitario, 2004). 
This profile is the reference point for identifying the competences that a given professional should possess in order to perform their role. ${ }^{78,79,80,81,82}$

The reference to performance in authentic situations and contexts requires using active, student-centred methodologies ${ }^{83,84,85,86}$ These may be designed within each subject or in the form of broader units (projects, modules or areas) ${ }^{87,88,89}$ The curriculum should therefore contain decisions with respect to the learning model and/or methods to be used, and the type of academic units to be employed to organise the programme, ${ }^{90,91}$ including the work time

78 Julia González and Robert Wagenaar, Tuning Educational Structures in Europe. Final Report - Phase 1 (Bilbao: Universidad de Deusto, 2003).

79 Julia González and Robert Wagenaar, eds., Tuning educational Structures in Europe. Universities contribution to the Bologna Process. Final Report. Pilot Project-Phase 2 (Bilbao: University of Deusto and University of Groningen, 2006).

${ }^{80}$ Universidad de Deusto, Pautas para la elaboración del Perfil Académico - Profesional de la Titulación (Bilbao: Universidad de Deusto, 2003).

${ }^{81}$ Universidad de Deusto, Orientaciones para la formulación y el desarrollo de competencias específicas (Bilbao: Universidad de Deusto, 2007).

82 ANECA, "Guía de Apoyo para la elaboración de la Memoria de verificación de Títulos Oficiales Universitarios,” 2015, http://www.aneca.es/content/download/12155/136031/file/ verifica_gm_guia_V05.pdf.

${ }^{83}$ Universidad de Deusto, Marco Pedagógico de la Universidad de Deusto (Bilbao: Universidad de Deusto, 2001).

${ }^{84}$ MEC, Propuesta para la Renovación de las metodologías educativas en la universidad (Madrid: MEC, Secretaría de Estado de Universidades, 2006), https://sede.educacion.gob.es/ publiventa/descarga.action?f_codigo_agc=12114_19.

${ }^{85}$ Mario de Miguel, coord., Metodologías de enseñanza y aprendizaje para el desarrollo de competencias: orientaciones para el profesorado universitario ante el Espacio Europeo de Educación Superior (Madrid: Alianza, 2006).

${ }^{86}$ John Biggs, Calidad del aprendizaje universitario (Madrid: Narcea, 2006).

${ }^{87}$ Mario de Miguel et al., Adaptación de los planes de estudio al proceso de Convergencia europea (Madrid: Dirección General de Universidades, MEC - Programa de Estudios y Análisis para la mejora de la calidad de la enseñanza y de la actividad del profesorado universitario, 2004).

${ }^{88}$ Mario de Miguel, coord., Metodologías de enseñanza y aprendizaje para el desarrollo de competencias: orientaciones para el profesorado universitario ante el Espacio Europeo de Educación Superior (Madrid: Alianza, 2006).

89 ANECA, "Guía de Apoyo para la elaboración de la Memoria de verificación de Títulos Oficiales Universitarios,” 2015, http://www.aneca.es/content/download/12155/136031/file/ verifica_gm_guia_V05.pdf.

${ }_{90}$ Mario de Miguel et al., Adaptación de los planes de estudio al proceso de Convergencia europea (Madrid: Dirección General de Universidades, MEC - Programa de Estudios y Análisis para la mejora de la calidad de la enseñanza y de la actividad del profesorado universitario, 2004).

91 ANECA, "Guía de Apoyo para la elaboración de la Memoria de verificación de Títulos Oficiales Universitarios,” 2015, http://www.aneca.es/content/download/12155/136031/file/ 
assigned to them..$^{92,93,94}$ The competences within the degree are to be detailed further at a later stage, using tools such as competence maps or curriculum grids to define how they will be acquired in the different units. ${ }^{95}$ Assessment structure also needs to be consistent with the methodological choices made, to determine the degree of acquisition of those competences, both upon completion of each unit and of the degree. This will establish the extent to which the outcomes in the graduate profile have been achieved. ${ }^{96,97,98,99,100}$

Some mechanisms also need to be introduced to monitor whether the plan is implemented in a coordinated manner, which include distributing the competences and content to be developed ${ }^{101}{ }^{102}$; specifying learning scenarios and activities and making spaces available for them; obtaining the necessary

verifica_gm_guia_V05.pdf.

92 European Comission, ECTS Users' Guide. European Credit Transfer and accumulation system and the diploma supplement (Brussels: Education and Culture DG, 2005).

${ }_{93}$ MEC, Real Decreto 1393/2007, de 29 de octubre, por el que se establece la ordenación de las enseñanzas universitarias oficiales, 2007, https://www.boe.es/boe/dias/2007/10/30/pdfs.

94 ANECA, "Guía de Apoyo para la elaboración de la Memoria de verificación de Títulos Oficiales Universitarios,” 2015, http://www .aneca.es/content/download/12155/136031/file/ verifica_gm_guia_V05.pdf.

${ }_{95}$ Universidad de Deusto, Orientaciones para la formulación y el desarrollo de competencias específicas (Bilbao: Universidad de Deusto, 2007).

96 Gonzalez, Julia y Wagenaar, Robert, eds., Tuning educational Structures in Europe. Informe final. Proyecto piloto -Fase II. La contribución de las universidades al proceso de Bolonia (Bilbao: University of Deusto and University of Groningen).

${ }_{97}$ Aurelio Villa and Manuel Poblete, Competence-based learning. A proposal for the assessment of generic competences (Bilbao: University of Deusto, 2009).

${ }_{98}$ European Comission, Using Learning Outcomes (Luxembourg: Publications Office of the European Union, 2011).

99 ANECA, "Guía de Apoyo para la redacción, puesta en práctica y evaluación de los Resultados del Aprendizaje,” 2013, http://www.aneca.es/content/download/12765/158329/ file/learningoutcomes_v02.pdf.

100 ANECA, "Guía de Apoyo para la elaboración de la Memoria de verificación de Títulos Oficiales Universitarios," 2015, http://www .aneca.es/content/download/12155/136031/file/ verifica_gm_guia_V05.pdf.

101 ANECA, "Guía de Apoyo para la elaboración de la Memoria de verificación de Títulos Oficiales Universitarios,” 2015, http://www .aneca.es/content/download/12155/136031/file/ verifica_gm_guia_V05.pdf.

102 ANECA, "Documento Marco: Evaluación para la renovación de la acreditación de títulos oficiales de Grado, Máster y Doctorado,” 2016, http://www.aneca.es/content/ download/12737/157930/file/acredita_documentomarco_v4b.pdf. 
resources; organising work time; ${ }^{103} 104$ enabling transversal procedures for assessment; ${ }^{105,106}$ scheduling meetings and arranging meeting places; using appropriate documents, repositories and digital applications, among others. ${ }^{107,108,109,110}$ See table 3 .

\subsection{Dimension 4: module/subject planning process}

One of the challenges faced by the teaching staff who put CBL into practice is the appropriate planning of their module or subject, taking the following key elements into consideration: ${ }^{111,112}$ the contribution to the graduate

103 Julia González and Robert Wagenaar, Tuning Educational Structures in Europe. Final Report - Phase 1 (Bilbao: Universidad de Deusto, 2003).

104 Julia González and Robert Wagenaar, eds., Tuning educational Structures in Europe. Universities contribution to the Bologna Process. Final Report. Pilot Project - Phase 2 (Bilbao: University of Deusto and University of Groningen, 2006).

105 ANECA, "Guía de Apoyo para la redacción, puesta en práctica y evaluación de los Resultados del Aprendizaje," 2013, http://www.aneca.es/content/download/12765/158329/ file/learningoutcomes_v02.pdf.

106 ANECA, "Documento Marco: Evaluación para la renovación de la acreditación de títulos oficiales de Grado, Máster y Doctorado," 2016, http://www.aneca.es/content/ download/12737/157930/file/acredita_documentomarco_v4b.pdf.

107 Mario de Miguel et al., Adaptación de los planes de estudio al proceso de Convergencia europea (Madrid: Dirección General de Universidades, MEC - Programa de Estudios y Análisis para la mejora de la calidad de la enseñanza y de la actividad del profesorado universitario, 2004).

108 Aurelio Villa and Ana García-Olalla, "Un sistema de garantía de calidad de la docencia: un estudio de caso," Revista Electrónica Interuniversitaria de Formación del Profesorado 17, no. 3 (2014): 65-78.

109 Ana García-Olalla, "El Portafolio Docente: Un instrumento para evaluación y mejora de la práctica docente," Revista CIDUI 2 (2014b): 1-13.

110 Manuel Poblete and Ana García-Olalla, Desarrollo de competencias y créditos transferibles. Experiencia multidisciplinar en el contexto universitario (Bilbao: Mensajero, 2007).

${ }^{111}$ Universidad de Deusto, Normas y Orientaciones para la Elaboración de Programas y Guías de Aprendizaje (Bilbao: Universidad de Deusto, 2007).

112 Ana García-Olalla and Elena Auzmendi, "Evaluación de la Planificación de la docencia en las asignaturas de Grado," in Libro de Actas CIDUI La Universidad una institución de la sociedad, 2012, http://www.cidui.org/revista-cidui12. 
profile and the acquisition of competences by students; ${ }^{113,114}$ the use of teaching-learning strategies; ${ }^{115}$ and the suitable assessment of the competences. . $^{116,117,118,119,120}$

Each degree qualification is intended to enable students to achieve a certain academic and professional profile. Therefore, the starting point in the planning process needs to be developing that profile and the prerequisites to be met by students. Each faculty member should define which specific and generic competences are sought within their particular module (or similar unit). ${ }^{121,122}$

The second key criterion is to specify which teaching-learning strategies will be used. The lecturer should: provide a pedagogical strategy that is coherent with the competences to be acquired by students, and consistent with the principles of autonomy and meaningful learning; plan the learning activities in detail, including the time needed to carry them out; provide all documents and supporting resources required for those activities; and establish the

${ }^{113}$ Pablo Beneitone, Julia González, and Robert Wagenaar, Meta-perfiles y perfiles. Una nueva aproximación a para las titulaciones en América Latina (Bilbao: Universidad de Deusto, 2014), http://www.tuningal.org/es/publicaciones/doc_download/122-meta-perfiles-yperfiles-una-nueva-aproximacion-para-las-titulaciones-en-america-latina-espanol.

${ }^{114}$ Gerardo Serpa, Adriana Falcón, and Elvia Isabel Echeverría, "Contribución de los meta-perfiles a mejorar la formación por competencias: el caso de la carrera de Enfermería en Uniandes," Revista de Ciencia, Tecnología e Innovación 3, no. 2 (2016) 1-16.

115 Mario de Miguel, coord., Metodologías de enseñanza y aprendizaje para el desarrollo de competencias: orientaciones para el profesorado universitario ante el Espacio Europeo de Educación Superior (Madrid: Alianza, 2006).

${ }^{116}$ Maria Lourdes Villardón, "Evaluación del aprendizaje para promover el desarrollo de competencias," Educatio siglo XXI 24 (2006): 57-76.

117 Aurelio Villa and Manuel Poblete, Competence-based learning. A proposal for the assessment of generic competences (Bilbao: University of Deusto, 2009).

118 María Paz Sanz and Laura Raquel Pedreño, "La planificación de evaluación de competencias en Educación Superior," Revista electrónica interuniversitaria de formación del profesorado 14, no. 1 (2011): 113-124.

${ }^{119}$ Raúl Fuentes and Lucía Amorós, "Evaluación de competencias: Un ejemplo en posgrado," Revista Electrónica de Desarrollo de Competencias (REDEC) 5, no. 1(2012): 1-22.

120 Jesús Jornet, José González, Jesús Suárez, and María Jesús Perales, "Diseños de evaluación de competencias: consideraciones acerca de los estándares en el dominio de las competencias,” Bordón 63, no. 1 (2011):125-145.

${ }^{121}$ Viviana Maura and Rosa Tirado, "Competencias genéricas y formación profesional: un análisis desde la docencia universitaria," Revista iberoamericana de educación 47 (2008): 185-209.

${ }^{122}$ Enric Rovira, "Competencias genéricas en la formación universitaria," Revista de Educação 325 (2001): 229-321. 
procedures, schedules and places for monitoring, tutoring and directing the learning process. ${ }^{123,124}$

The third key criterion is to set forth a suitable system for the assessment of competences, ${ }^{125,126}$ one of the most complicated aspects for teaching staff. ${ }^{127}$ In order to put into competence-based assessment into practice, the lecturer needs to formulate the learning outcomes and/or indicators to be used for assessing and giving feedback to students with respect to their progress in acquiring the necessary competences; ${ }^{128,129}$ select the techniques and instruments to be employed to collect the relevant information, during and at the end of the process; and design the marking scheme to be used (weighting of each competence/indicator towards the final mark), reflecting the degree of acquisition of the competences both throughout the process and upon completion of the module programme. ${ }^{130,131,132}$ See table 4 .

${ }^{123}$ Mario de Miguel, coord., Metodologías de enseñanza y aprendizaje para el desarrollo de competencias: orientaciones para el profesorado universitario ante el Espacio Europeo de Educación Superior (Madrid: Alianza, 2006).

124 Ana García-Olalla and Elena Auzmendi, "Evaluación de la Planificación de la docencia en las asignaturas de Grado," in Libro de Actas CIDUI La Universidad una institución de la sociedad, 2012, http://www.cidui.org/revista-cidui12.

125 Aurelio Villa and Manuel Poblete, "Evaluación de competencias genéricas: principios, oportunidades y limitaciones," Bordón 63, no. 1 (2011): 147-170.

${ }^{126}$ Elena Cano, "La evaluación por competencias en la educación superior," Profesorado 12, no. 3 (2011): 1-16.

127 Juan Manuel Álvarez, "Evaluar el aprendizaje en una enseñanza centrada en competencias," in Educar por competencias, ¿qué hay de nuevo?, ed. José Gimeno (Madrid: Morata, 2008).

${ }_{128}$ Aurelio Villa y Manuel Poblete, "Evaluación de competencias genéricas: principios, oportunidades y limitaciones," Bordón 63, no. 1 (2011): 147-170.

129 ANECA, "Guía de Apoyo para la redacción, puesta en práctica y evaluación de los Resultados del Aprendizaje,” 2013, http://www.aneca.es/content/download/12765/158329/ file/learningoutcomes_v02.pdf.

${ }^{130}$ Universidad de Deusto, Normas y Orientaciones para la Elaboración de Programas y Guías de Aprendizaje (Bilbao: UD, 2007).

${ }^{131}$ G Ana García-Olalla and Elena Auzmendi, "Evaluación de la Planificación de la docencia en las asignaturas de Grado," in Libro de Actas CIDUI La Universidad una institución de la sociedad, 2012, http://www.cidui.org/revista-cidui12.

132 Aurelio Villa and Manuel Poblete, "Evaluación de competencias genéricas: principios, oportunidades y limitaciones,” Bordón 63, no. 1 (2011): 147-170. 


\subsection{Dimension 5: Teaching practices and assessment}

After the planning process has been completed, the focus is shifted to teaching practices. How faculty members should behave towards students, the nature of their teaching practices and the lecturer-student relationship all mark a change from a lecturer- and content-based approach to a student-centred learning process that seeks to provide an overall education. ${ }^{133}$

The first criterion is the type of methodologies used and their pertinence to competence-based learning. ${ }^{134,135,136,137}$ Active methodologies should be employed and their purpose should be conveyed to students, thus promoting their motivation and involvement, and fomenting autonomous and meaningful learning. ${ }^{138,139,140,141,142}$ The use of a broad range of methodologies (PBL, cooperative learning, case studies, etc.) and/or techniques (simulations, debates, competitions, role-playing, etc.) is advised. This means that teaching practices can be adapted to different types of students, contents and

133 Águeda Benito and Ana Cruz, Nuevas claves para la docencia universitaria en el Espacio Europeo de Educación Superior: en el espacio europeo de educación superior (Madrid: Narcea, 2005).

134 Águeda Benito and Ana Cruz, Nuevas claves para la docencia universitaria en el Espacio Europeo de Educación Superior: en el espacio europeo de educación superior (Madrid: Narcea, 2005).

135 John Biggs, Calidad del aprendizaje universitario (Madrid: Narcea, 2006).

${ }^{136}$ María Fernández, "From the Teaching-Based Model to the Learning-Based Model: A Comparative Study," Procedia-Social and Behavioral Sciences 237 (2017): 678-684.

137 Ana García-Olalla, "El Portafolio Docente: Un instrumento para evaluación y mejora de la práctica docente," Revista CIDUI 2 (2014): 1-13.

138 Águeda Benito and Ana Cruz, Nuevas claves para la docencia universitaria en el Espacio Europeo de Educación Superior: en el espacio europeo de educación superior (Madrid: Narcea, 2005).

${ }^{139}$ Francisco Javier Tejedor and Ana García-Valcárcel, "Causas del bajo rendimiento del estudiante universitario (en opinión de los profesores y alumnos). Propuesta de mejora en el marco del EEES," Revista de Educación 342 (2007): 443- 472.

${ }_{140}$ Rufino Cano, "Tutoría universitaria y aprendizaje por competencias ¿Cómo lograrlo?," Revista electrónica interuniversitaria de formación del profesorado 12, no. 1 (2009): 181-204.

${ }^{141}$ Rosa García, Sonsoles Guerra, Natalia González, and Emilio Álvarez, "Estudio exploratorio de las percepciones del profesorado universitario respecto a la gestión de la docencia," Educación XXI, 13, no. 2 (2010): 163-184.

${ }_{142}$ María Fernández, "From the Teaching-Based Model to the Learning-Based Model: A Comparative Study,” Procedia-Social and Behavioral Sciences 237 (2017): 678-684. 
competences. ${ }^{143,144,145}$ It is also recommendable to propose contextualised, reallife activities, ${ }^{146,147,148}$ and to use ICT to support the process. ${ }^{149,150}$ Any additional necessary conditions and resources, both human and material, should also be made available. ${ }^{151,152}$

The second criterion is related to the scope and importance of student guidance and tutoring. This task has come to play an essential role, as it gives direction to the learning process and helps ensure that it takes place in an autonomous and responsible manner. It is difficult to deliver a competencebased module (or similar unit) without the lecturer guiding and supporting

143 Águeda Benito and Ana Cruz, Nuevas claves para la docencia universitaria en el Espacio Europeo de Educación Superior: en el espacio europeo de educación superior (Madrid: Narcea, 2005).

${ }^{144}$ Rosa María Rodríguez, "Mejora continua de la práctica docente universitaria: una experiencia desde el proceso de convergencia del EEES," Revista Electrónica Interuniversitaria de Formación del Profesorado 10, no. 1 (2007): 1-8.

${ }^{145}$ María Fernández, "From the Teaching-Based Model to the Learning-Based Model: A Comparative Study,” Procedia-Social and Behavioral Sciences 237 (2017): 678-684.

146 Amparo Fernández, "Metodologías activas para la formación de competencias," Educatio siglo XXI, 24 (2006): 35-56.

${ }^{147}$ María Pallisera, Judit, Fullana, Anna Planas, and Arantza Del Valle, "La adaptación al espacio europeo de educación superior en España: los cambios/retos que implica la enseñanza basada en competencias y orientaciones para responder a ellos," Revista Iberoamericana de Educación 52, no. 4 (2010): 1-13.

${ }^{148}$ Frida Díaz and Ramses Barroso, "Diseño y validación de una propuesta de evaluación auténtica de competencias en un programa de formación de docentes de educación básica en México," Perspectiva Educacional 53, no. 1 (2014): 36-56.

149 Jesús Salinas, "Innovación docente y uso de las TIC en la enseñanza universitaria," RUSC, Universities and Knowledge Society Journal 1, no. 1 (2004) 1-16.

${ }^{150}$ Carlos Ferro, Ana Isabel Martínez, and María del Carmen Otero, "Ventajas del uso de las TICs en el proceso de enseñanza-aprendizaje desde la óptica de los docentes universitarios españoles," EDUTEC, Revista Electrónica de Tecnología Educativa 29 (2009):1-12.

${ }^{151}$ Rufino Cano, "Modelo organizativo para la planificación y desarrollo de la Tutoría Universitaria en el marco del proceso de convergencia europea en Educación Superior," Revista Interuniversitaria de Formación del Profesorado 22, no. 1 (2008): 185-206.

${ }^{152}$ Rosa García, Sonsoles Guerra, Natalia González, and Emilio Álvarez, "Estudio exploratorio de las percepciones del profesorado universitario respecto a la gestión de la docencia," Educación XXI, 13, no. 2 (2010): 163-184. 
students throughout the process..$^{153,154,155,156}$ Additionally, as noted by several authors, ${ }^{157,158,159}$ tutoring should not only be focused on teaching-learning issues, linked to the monitoring of the learning process within a given module, but it should also have a guiding role, including providing support on personal issues and concerns regarding career direction and advice.

The third criterion is focused on how the subject or module would be assessed, which should be consistent with the competences sought in the programme. ${ }^{160,161,162,163,164}$ This should cover progress both in terms of specific competences and of transversal or generic competences. The CALOHEE

153 Águeda Benito and Ana Cruz, Nuevas claves para la docencia universitaria en el Espacio Europeo de Educación Superior: en el espacio europeo de educación superior (Madrid: Narcea, 2005).

154 Rufino Cano, "Modelo organizativo para la planificación y desarrollo de la Tutoría Universitaria en el marco del proceso de convergencia europea en Educación Superior," Revista Interuniversitaria de Formación del Profesorado 22, no. 1 (2008): 185-206.

155 Eva María Torrecilla, María José Rodríguez, María Esperanza Herrera, and Juan Francisco Martín, "Evaluación de calidad de un proceso de tutoría de titulación universitaria: la perspectiva del estudiante de nuevo ingreso en educación," REOP, Revista Española de Orientación y Psicopedagogía 24, no. 2 (2013): 79-99.

156 María Fernández, "From the Teaching-Based Model to the Learning-Based Model: A Comparative Study,” Procedia-Social and Behavioral Sciences 237 (2017): 678-684.

${ }^{157}$ Francisco Javier Tejedor and Ana García-Valcárcel, "Causas del bajo rendimiento del estudiante universitario (en opinión de los profesores y alumnos). Propuesta de mejora en el marco del EEES," Revista de Educación 342 (2007): 443- 472.

158 Rufino Cano, "Modelo organizativo para la planificación y desarrollo de la Tutoría Universitaria en el marco del proceso de convergencia europea en Educación Superior," Revista Interuniversitaria de Formación del Profesorado 22, no. 1 (2008): 185-206.

159 Eva María Torrecilla, María José Rodríguez, María Esperanza Herrera, and Juan Francisco Martín, "Evaluación de calidad de un proceso de tutoría de titulación universitaria: la perspectiva del estudiante de nuevo ingreso en educación," REOP, Revista Española de Orientación y Psicopedagogía 24, no. 2 (2013): 79-99.

160 Águeda Benito and Ana Cruz, Nuevas claves para la docencia universitaria en el Espacio Europeo de Educación Superior: en el espacio europeo de educación superior (Madrid: Narcea, 2005).

161 Víctor López-Pastor, "El papel de la evaluación formativa en el proceso de convergencia hacia el EEES: Análisis del estado de la cuestión y presentación de un sistema de intervención," Revista interuniversitaria de formación del profesorado 20, no. 3 (2006): 93119.

162 Víctor López-Pastor, "El papel de la evaluación formativa en la evaluación por competencias: aportaciones de la red de evaluación formativa y compartida en docencia universitaria," REDU, Revista de Docencia Universitaria 9, no. 1 (2011): 159-173.

${ }_{163}$ Maria Lourdes Villardón, "Evaluación del aprendizaje para promover el desarrollo de competencias," Educatio siglo XXI 24 (2006): 57-76.

164 Ana García-Olalla, "El Portafolio Docente: Un instrumento para evaluación y mejora de la práctica docente," Revista CIDUI 2 (2014): 1-13. 
Project of the European Union offers a complete example of how to develop a competence based learning assessment of students based on 5 areas of knowledge: Engineering (Civil Engineering), Health Care (Nursing), Humanities (History), Natural Sciences (Physics) and Social Sciences (Education). ${ }^{165}$ A correct assessment involves the use of a multitude of tools and techniques ${ }^{166}$. It also entails transparency in managing the process: students should be informed in advance of the instruments, criteria, indicators and weighting that will be used in the assessment of a given module, ${ }^{167,168}$ and of the assessment schedule. ${ }^{169}$

Assessment should not be merely summative but formative in nature, with feedback to be regarded as a key element for a student's progress. Obtaining feedback on how to learn, on the difficulties and obstacles to be overcome, and on the errors to be corrected is at the core of improvement. This results in deriving optimal benefits from the module. ${ }^{170,171}$ It is also advisable to involve different agents in the assessment process, including the lecturer, their

165 CALOHEE, "Measuring and Comparing Achievements of Learning Outcomes in Higher Education in Europe," last modified 2019, https://www .calohee.eu/main-objectives/.

166 Victor López-Pastor, "El papel de la evaluación formativa en la evaluación por competencias: aportaciones de la red de evaluación formativa y compartida en docencia universitaria," REDU, Revista de Docencia Universitaria 9, no. 1 (2011): 159-173.

167 Águeda Benito and Ana Cruz, Nuevas claves para la docencia universitaria en el Espacio Europeo de Educación Superior: en el espacio europeo de educación superior (Madrid: Narcea, 2005).

168 Maria Lourdes Villardón, "Evaluación del aprendizaje para promover el desarrollo de competencias," Educatio siglo XXI 24 (2006): 57-76.

169 Víctor López-Pastor, "El papel de la evaluación formativa en la evaluación por competencias: aportaciones de la red de evaluación formativa y compartida en docencia universitaria," REDU, Revista de Docencia Universitaria 9, no. 1 (2011): 159-173.

${ }^{170}$ Universidad de Deusto, Marco Pedagógico de la Universidad de Deusto (Bilbao: Universidad de Deusto, 2001).

171 Ana García-Olalla, "El Portafolio Docente: Un instrumento para evaluación y mejora de la práctica docente," Revista CIDUI 2 (2014): 1-13. 
colleagues, and students themselves, ${ }^{172,173,174,175}$ and to rely on ICT to support the process. ${ }^{176,177,178}$ See table 5 .

\subsection{Dimension 6: Module review and improvement}

Several authors have included lecturers' reflections on their own practice in their competence-based teaching-learning models. ${ }^{179,180,181,182,183,184,185}$ The

172 Águeda Benito and Ana Cruz, Nuevas claves para la docencia universitaria en el Espacio Europeo de Educación Superior: en el espacio europeo de educación superior (Madrid: Narcea, 2005).

173 Víctor López-Pastor, "El papel de la evaluación formativa en la evaluación por competencias: aportaciones de la red de evaluación formativa y compartida en docencia universitaria," REDU, Revista de Docencia Universitaria 9, no. 1 (2011): 159-173.

${ }^{174}$ Maria Lourdes Villardón, "Evaluación del aprendizaje para promover el desarrollo de competencias," Educatio siglo XXI 24 (2006): 57-76.

175 María Teresa Padilla and Javier Gil, "La evaluación orientada al aprendizaje en la Educación Superior: condiciones y estrategias para su aplicación en la docencia universitaria," Revista española de pedagogía 241 (2008): 467-485.

176 Jesús Salinas, "Innovación docente y uso de las TIC en la enseñanza universitaria," RUSC, Universities and Knowledge Society Journal 1, no. 1 (2004) 1-16.

177 Águeda Benito and Ana Cruz, Nuevas claves para la docencia universitaria en el Espacio Europeo de Educación Superior: en el espacio europeo de educación superior (Madrid: Narcea, 2005).

178 Susana Olmos-Migueláñez and María José Rodríguez-Conde, "El profesorado universitario ante la e-evaluación del aprendizaje," ESE. Estudios Sobre Educación. Revista semestral del Departamento de Educación de la Facultad de Filosofía y Letras de la Universidad de Navarra 20 (2011): 181-202.

179 Miguel Ángel Zabalza, Competencias docentes del profesorado universitario. Calidad $y$ desarrollo profesional (Madrid: Narcea, 2003).

${ }^{180}$ Miguel Valcarcel, coord.,La preparación del profesorado universitario para la convergencia europea en educación superior. Informe Investigación, Proyecto EA2003-0040, 2005.

${ }^{181}$ Francisco Ayala, El modelo de formación por competencias, 2008, http://www. modelo.edu.mx/univ/mcom.ppt.

182 José Tejada, "Competencias Docentes," Profesorado. Revista de curriculum y formación del profesorado 13, no. 2 (2009): 1-15.

183 José María Marbán, coord., Análisis de las herramientas de evaluación de la Calidad Docente mediante contrastes basados en Estándares Internacionales de Excelencia (Madrid: Ministerio de Educación, Cultura y Deporte, Proyecto EA2011-0113, 2012).

184 Aurelio Villa and Ana García-Olalla, "Un sistema de garantía de calidad de la docencia: un estudio de caso," Revista Electrónica Interuniversitaria de Formación del Profesorado 17, no. 3 (2014): 65-78.

185 Ana García-Olalla, "Estándares para evaluar la calidad docente," in La Innovación Educativa para transformar la sociedad multicultural: El papel de las Universidades, ed. Aurelio Villa (Bogotá: FIIU, 2014). 
process for the review and improvement of a given module should be part of the teaching process at different points, ${ }^{186}$ but it is particularly important at the end of the academic year. It is at this time that the strengths and weaknesses should be identified, and changes and actions need to be proposed to improve the way in which students should acquire the relevant competences the following year. ${ }^{187}$ Improvement may involve making minor, specific changes, including those to teaching plans, the use of teaching time, and the methods, techniques and/or activities for teaching-learning and assessment. These do not require excessive time and training on the part of the lecturer. In other cases, major changes may be required, which may demand the faculty member to participate in specific training. In the case of university lecturers and professors, training is important, since they generally begin their teaching career without any specific training in teaching methods. ${ }^{188}$

This reflection process should rely on information from different sources: students, colleagues, academic managers and lecturers themselves, ${ }^{189,190,191}$ although it is mainly students' evaluations that are usually taken as a reference point. Moreira and Santos ${ }^{192}$ noted that a lecturer's self-assessment provides a more substantive reflection on their performance than the analysis made by students. In this regard, Montoya ${ }^{193}$ referred to the 'assessment of assessments'

186 Benilde García-Cabrero, Javier Loredo, and Guadalupe Carranza, “Análisis de la práctica educativa de los docentes: pensamiento, interacción y reflexión,” Revista Electrónica de Investigación Educativa 10 (2008): 1-15.

187 Ana García-Olalla, "El Portafolio Docente: Un instrumento para evaluación y mejora de la práctica docente," Revista CIDUI 2 (2014): 1-13.

${ }^{188}$ Leticia Elizalde, Leticia and Rafael Reyes, "Elementos clave para la evaluación del desempeño de los docentes," Revista electrónica de investigación educativa 10 (2008): 1-8.

189 ANECA, "Programa DOCENTIA (Programa de apoyo para la evaluación de la actividad docente del profesorado universitario). Integración y actualización de la documentación del Programa," 2015. v1, 2015, http://www.aneca.es/content/ download/13305/164819/file/DOCENTIA_nuevadoc_v1_final.pdf.

190 José María Marbán, coord., Análisis de las herramientas de evaluación de la Calidad Docente mediante contrastes basados en Estándares Internacionales de Excelencia (Madrid: Ministerio de Educación, Cultura y Deporte, Proyecto EA2011-0113, 2012).

${ }^{191}$ Universidad de Deusto, Manual para la Garantía Interna de Calidad Docente: Modelo de desarrollo profesional en la UD (Bilbao: Universidad de Deusto, 2007).

${ }^{192}$ Luis Miguel Moreira and Miguel Angel Santos, "Evaluando la enseñanza en la educación superior: percepciones de docentes y discentes," Revista Electrónica de investigación Educativa 18, no. 3 (2016): 19-36.

193 Juny Montoya, "Evaluar las evaluaciones: Diseño puesta a prueba de un sistema de evaluación para el mejoramiento de la docencia en unidades," Revista iberoamericana de evaluación educativa 5, no. 1 (2012): 48-58. 
as a way of promoting reflection processes on teaching practices among faculty members.

The analysis of teaching practices at the end of the process includes analysing students' outcomes, ${ }^{194}$ that is, the meanings students have managed to construct concerning the relevant competences, not only in terms of their opinion about the teaching practices involved, or their perception of the learning attained. ${ }^{195}$ In so doing, the lecturer becomes involved beyond the typical role in assessment processes (an individual being evaluated through standardised instruments), and fosters full participation in the evaluation and the creation of new educational goals.

Teaching practices may be reflected on either by faculty members on an individual basis, or on a collegial basis (between the lecturer and their line manager, or between lecturers). Montoya ${ }^{196}$ proposed an assessment system that includes an interview. The study found that most lecturers saw the interview as a useful opportunity to reflect on their teaching practice. Some of them also clearly identified ways of improving their courses, and their specific training needs. It is important to take into account that implementing policies and strategies for faculty members' professional development requires that the HEI be receptive. An institution that is willing to acknowledge their needs, establish priorities, decide how and on what terms professional development will take place, and assess the outcomes, ${ }^{197}$ operating on a coordinated basis with other performance evaluation programmes and incentive schemes. ${ }^{198}$ See table 6 .

194 Ana García-Olalla, "El Portafolio Docente: Un instrumento para evaluación y mejora de la práctica docente," Revista CIDUI 2 (2014): 1-13.

195 Benilde García-Cabrero, Javier Loredo, and Guadalupe Carranza, "Análisis de la práctica educativa de los docentes: pensamiento, interacción y reflexión," Revista Electrónica de Investigación Educativa 10 (2008): 1-15.

196 Juny Montoya, "Evaluar las evaluaciones: Diseño puesta a prueba de un sistema de evaluación para el mejoramiento de la docencia en unidades," Revista iberoamericana de evaluación educativa 5, no. 1 (2012): 48-58.

${ }^{197}$ Beatrice Ávalos, "El desarrollo profesional continuo de los docentes: lo que nos dice la experiencia internacional y de la región latinoamericana," Revista Pensamiento Educativo 41, no. 2 (2017): 77-79.

198 ANECA, "Programa DOCENTIA (Programa de apoyo para la evaluación de la actividad docente del profesorado universitario). Integración y actualización de la documentación del Programa," 2015. v1, 2015, http://www.aneca.es/content/ download/13305/164819/file/DOCENTIA_nuevadoc_v1_final.pdf. 


\subsection{Dimension 7: Degree programme review and improvement}

This Dimension is related to Dimension 3, which deals with degree programme design. In this way the process comes full circle, and a number of mechanisms are highlighted that need to be put in place to review and improve the degree after it has been designed and implemented. These mechanisms are intended to ensure that a systematic review and improvement process takes place; and that this process is open, flexible, relevant and objective, by welcoming multiple voices and perspectives to participate.

Certain institutional conditions need to be created to facilitate the review and improvement process, including: identifying needs, designing improvement plans, and incorporating the changes required as they are proposed, with no need to obtain external approval. ${ }^{199,200}$ For the sake of objectivity, and to ensure that a rigorous process takes place, a person or a body could be entrusted with the monitoring tasks (one that is preferably different from the person or the body in charge of planning and implementing the changes).

Another key aspect at this stage is involving different agents in the process, particularly in terms of identifying the areas to be improved. ${ }^{201,202,203}$ In addition to consulting faculty members, the points of view of students, graduates and employers should be included. Students are in a privileged position to detect any potential overlapping areas and shortcomings in the degree programme, and also to identify any mismatches between the level of competences at the

199 Mario de Miguel et al., Adaptación de los planes de estudio al proceso de Convergencia europea (Madrid: Dirección General de Universidades, MEC - Programa de Estudios y Análisis para la mejora de la calidad de la enseñanza y de la actividad del profesorado universitario, 2004).

200 Ana García-Olalla, "Estándares para evaluar la calidad docente," in La Innovación Educativa para transformar la sociedad multicultural: El papel de las Universidades, ed. Aurelio Villa (Bogotá: FIIU, 2014).

201 Julia González and Robert Wagenaar, eds., Tuning educational Structures in Europe. Universities contribution to the Bologna Process. Final Report. Pilot Project - Phase 2 (Bilbao: University of Deusto and University of Groningen, 2006).

${ }^{202}$ Pablo Beneitone, César Esquetini, Julia González, Maira Maletá, Gabriela Siufi, and Robert Wagenaar, eds., Reflexiones y perspectivas de la educación superior en América latina. Informe Final - Proyecto Tuning - América Latina, 2004/2007 (Bilbao and Groningen, University of Deusto, 2008).

${ }^{203}$ ANECA, "Documento Marco: Evaluación para la renovación de la acreditación de títulos oficiales de Grado, Máster y Doctorado," 2016, http://www.aneca.es/content/ download/12737/157930/file/acredita_documentomarco_v4b.pdf. 
start and the level of attainment throughout their learning process. ${ }^{204,205,206}$ The contribution of graduates is critical, because they are aware of the programme's strengths and weaknesses as regards future employability and performing other roles in society. Employers and other members of society who are involved in graduates' entry into the job market and society itself have a good knowledge of the needs and requirements for this to happen successfully.

It is important that faculty members act on a collegial basis, as the degree programme is the result of a collective effort and its coherence and integrity must be preserved. ${ }^{207,208,209,210}$ The teaching staff should: have mechanisms that promote a structured reflection on how their module contributes to the acquisition of the competences provided in the graduate profile; receive suggestions from different agents; and create spaces where faculty members within the same degree can share their views and design a joint improvement plan. ${ }^{211,212,213}$ See table 7 .

${ }^{204}$ Catherine Bovill, Cathy Bulley, and Kate Morss, "Engaging and empowering firstyear students through curriculum design: perspectives from the literature," Teaching in Higher Education 16, no. 2 (2011): 197-209.

${ }^{205}$ Catherine Bovill, Alison Cook-Sather, and Peter Felten, "Students as co-creators of teaching approaches, course design, and curricula: implications for academic developers," International Journal for Academic Development 16, no. 2 (2011): 133-145.

${ }^{206}$ Simon Brooman, Sue Darwent, and A. Pimor, "The student voice in higher education curriculum design: is there value in listening?," Innovations in Education and Teaching International 52, no. 6 (2015): 663-674.

207 ENQA, Standards and guidelines for Quality Assurance in European Higher Education Area (Helsinki: ENQA, 2005), http://www.enqa.net/bologna.lasso.

${ }^{208}$ ENQA, Standards and guidelines for Quality Assurance in European Higher Education Area (Brussels, Belgium, 2015), http://www.enqa.eu/index.php/home/esg/.

209 Julia González and Robert Wagenaar, eds., Tuning educational Structures in Europe. Universities contribution to the Bologna Process. Final Report. Pilot Project - Phase 2 (Bilbao: University of Deusto and University of Groningen, 2006).

${ }^{210}$ Pablo Beneitone, César Esquetini, Julia González, Maira Maletá, Gabriela Siufi, and Robert Wagenaar, eds., Reflexiones y perspectivas de la educación superior en América latina. Informe Final - Proyecto Tuning - América Latina, 2004/2007 (Bilbao and Groningen, University of Deusto, 2008).

211 Aurelio Villa and Ana García-Olalla, "Un sistema de garantía de calidad de la docencia: un estudio de caso," Revista Electrónica Interuniversitaria de Formación del Profesorado 17, no. 3 (2014): 65-78.

${ }^{212}$ ANECA, "Guía de Apoyo para la redacción, puesta en práctica y evaluación de los Resultados del Aprendizaje,” 2013, http://www.aneca.es/content/download/12765/158329/ file/learningoutcomes_v02.pdf.

${ }^{213}$ ANECA, "Documento Marco: Evaluación para la renovación de la acreditación de títulos oficiales de Grado, Máster y Doctorado,” 2016, http://www.aneca.es/content/ download/12737/157930/file/acredita_documentomarco_v4b.pdf. 


\section{Discussion and conclusions}

The Bologna Declaration marked the beginning of a profound university reform that introduced, among other aspects, a CBL approach that advocates the overall development of students, both in specific and transversal competences. This approach is intended to enable them to adapt to and successfully address the issues and changes emerging in a complex, globalised world. Introducing it has not been an easy task, as it involves transforming the previous ways of doing things and affects the different areas and processes of university education. This study provides a comprehensive model for the analysis and assessment of the degree of implementation of CBL in the different universities. The proposed model seeks to make an original contribution, as it is a comprehensive 7-dimension model of analysis, with individual criteria and indicators for each dimension. While some partial analytical models have been proposed that have focused on a particular dimension of analysis, no comprehensive models have been found in the literature that are similar or an alternative to the one described here.

From the seven dimensions included in the model, two review the contextual aspects that surround the implementation of CBL: the national regulatory framework and the HEI's regulatory framework. Three dimensions describe the process for the development of CBL in the institution, which concerns degree programme design, module planning and teaching practices. The last two dimensions analyse the outcomes obtained and review the planning process, both on a degree and on a module basis. The breakdown of each dimension into criteria and indicators resulted from a literature review that focused on the most important aspects to be assessed in each of the dimensions. Although the model has been evaluated by eight experts, it would be interesting to test it through individual interviews or focus groups with university lecturers and managers. In fact, it is going to be tested in two Latin American universities during the next academic year. Also, even though the model has been developed in the context of Spain (as part of the European Union) and Latin America, it would be desirable that it may be contrasted with possible good practices in other regions of the world, and in particular in institutions where Tuning project has been implemented.

This model is not intended to be a single, finished model, but to serve as a framework for HEIs interested in evaluating the degree of implementation of CBL in their degree qualifications, so that they can adapt and reach a consensus through participatory processes within their institution. It is also essential to bear in mind that the university context is ever-changing and therefore, the model seeks to be dynamic and subject to changes and updates. 
The model can serve as a basis for the design of different assessment instruments according to the dimensions identified, from a quantitative, qualitative or mixed perspective. Both the model presented here and any tools that may result from it would be ultimately aimed at guiding the analysis of the situation and the decision-making process, so that they contribute to improving the acquisition of competences among university students.

\section{Bibliography}

Acebedo-Afanador, Manuel José, Inmaculada Aznar-Díaz, and Francisco Javier HinojoLucena. "Instrumentos para la evaluación del aprendizaje basado en competencias: Estudio de caso." Información Tecnológica 28, no. 3 (2017): 107-118.

Álvarez, Juan Manuel. "Evaluar el aprendizaje en una enseñanza centrada en competencias". In Educar por competencias, ¿qué hay de nuevo?, edited by José Gimeno, 206-235. Madrid: Morata, 2008.

Álvarez, Pedro Ricardo. Competencias genéricas en la enseñanza universitaria. De la tutoría formativa a la integración curricular. Málaga: Aljibe, 2016.

ANECA. "Guía de Apoyo para la redacción, puesta en práctica y evaluación de los Resultados del Aprendizaje." Last modified 2013. http://www.aneca.es/content/ download/12765/158329/file/learningoutcomes_v02.pdf.

"Guía de Apoyo para la elaboración de la Memoria de verificación de Títulos Oficiales Universitarios." Last modified 2015. http://www.aneca.es/content/ download/12155/136031/file/verifica_gm_guia_V05.pdf.

. "Programa DOCENTIA (Programa de apoyo para la evaluación de la actividad docente del profesorado universitario). Integración y actualización de la documentación del Programa." Last modified 2015. http://www.aneca.es/content/ download/13305/164819/file/DOCENTIA_nuevadoc_v1_final.pdf.

. "Documento Marco: Evaluación para la renovación de la acreditación de títulos oficiales de Grado, Máster y Doctorado.” Last modified 2016. http://www.aneca.es/ content/download/12737/157930/file/acredita_documentomarco_v4b.pdf.

Aránega, Susana. De la detección de las necesidades de formación pedagógica a la elaboración de un plan de formación en la sociedad. Barcelona: Octaedro, 2013.

Ávalos, Beatrice. "El desarrollo profesional continuo de los docentes: lo que nos dice la experiencia internacional y de la región latinoamericana." Revista Pensamiento Educativo 41, no. 2 (2007): 77-79.

Ayala, Francisco. "El modelo de formación por competencias." Last modified 2008. http://www.modelo.edu.mx/univ/mcom.ppt.

Beneitone, Pablo, César Esquetini, Julia González, Maira Maletá, Gabriela Siufi, and Robert Wagenaar, eds. Reflexiones y perspectivas de la educación superior en América latina. Informe Final - Proyecto Tuning - América Latina, 2004/2007. Bilbao: UD and University of Groningen, 2008. 
Beneitone, Pablo, Julia González, and Robert Wagenaar. "Meta-perfiles y perfiles. Una nueva aproximación a para las titulaciones en América Latina." Bilbao: UD. Last modified 2014. http://www.tuningal.org/es/publicaciones/doc_download/122-metaperfiles-y-perfiles-una-nueva-aproximacion-para-las-titulaciones-en-america-latinaespanol.

Benito, Águeda, and Ana Cruz. Nuevas claves para la docencia universitaria en el Espacio Europeo de Educación Superior. Madrid: Narcea, 2005.

Biggs, John. Calidad del aprendizaje universitario. Madrid: Narcea, 2006.

Bisquerra, Rafael. Metodología de la investigación educativa. Madrid: La Muralla, 2009.

"Bologna Declaration." Last modified 1999, http://www.ehea.info/media.ehea.info/file/ Ministerial_conferences/02/8/1999_Bologna_Declaration_English_553028.pdf.

Bologna Working Group on Qualifications Framework. "A Framework for Qualifications of the European Higher Education Area.” Copenhaguen, Ministry of Science, Technology and Innovation, Last modified 2005, http://ecahe.eu/w/images/7/76/A Framework_for_Qualifications_for_the_European_Higher_Education_Area.pdf.

Bovill, Catherine, Cathy Bulley, and Kate Morss. "Engaging and empowering first-year students through curriculum design: perspectives from the literature." Teaching in Higher Education 16, no. 2 (2011): 197-209.

Bovill, Catherine, Alison Cook-Sather, and Peter Felten. "Students as co-creators of teaching approaches, course design, and curricula: implications for academic developers." International Journal for Academic Development 16, no. 2 (2011): 133-145.

Bricall, José. Universidad 2000. Madrid: CRUE, 2000.

Brooman, Simon, Sue Darwent, and A Pimor. "The student voice in higher education curriculum design: is there value in listening?" Innovations in Education and Teaching International 52, no. 6 (2015): 663-674.

CALOHEE, "Measuring and Comparing Achievements of Learning Outcomes in Higher Education in Europe.”'Last modified 2019,https:/www.calohee.eu/main-objectives/

Calvo-Bernardino, Antonio, and Ana Cristina Mingorance-Arnáiz. "La estrategia de las universidades frente al Espacio Europeo de Educación Superior." Revista Complutense de Educación 20, no. 2 (2009): 319-342.

Cano, Elena. "La evaluación por competencias en la educación superior." Profesorado 12, no. 3 (2011): 1-16.

Cano, Rufino. "Modelo organizativo para la planificación y desarrollo de la Tutoría Universitaria en el marco del proceso de convergencia europea en Educación Superior." Revista Interuniversitaria de Formación del Profesorado 22, no. 1 (2008): 185-206.

."Tutoría universitaria y aprendizaje por competencias ¿Cómo lograrlo?” Revista electrónica interuniversitaria de formación del profesorado 12, no. 1 (2009): 181204.

Cardoso, Sonia, Orlanda Tavares, and Cristina Sin. "The quality of teaching staff: higher education institutions' compliance with the European Standards and Guidelines for Quality Assurance - the case of Portugal." Educational Assessment, Evaluation and Accountability 27, no. 3 (2015): 205-222. 
European Commission. ECTS Users' Guide. European CreditTransfer and accumulation system and the diploma supplement. Brussels: Education and Culture DG, 2005.

. The European Qualifications Framework for Lifelong Learning (EQF). Luxembourg: Publications Office of the European Union, 2008.

. Using Learning Outcomes. Luxembourg: Publications Office of the European Union, 2011.

European Commission/EACEA/Eurydice. The European Higher Education Area in 2015: Implementation Report. Luxembourg: Publications Office of the European Union, 2015.

De Miguel, Mario, coord. Adaptación de los planes de estudio al proceso de Convergencia europea. Madrid: Dirección General de Universidades, MEC - Programa de Estudios y Análisis para la mejora de la calidad de la enseñanza y de la actividad del profesorado universitario, 2004.

De Miguel, Mario, coord. Metodologías de enseñanza y aprendizaje para el desarrollo de competencias: orientaciones para el profesorado universitario ante el Espacio Europeo de Educación Superior. Madrid: Alianza, 2006.

Delors, Jacques, coord. La educación encierra un tesoro. Informe a la UNESCO de la Comisión Internacional sobre la educación para el siglo XXI. París: UNESCO Santillana, 1998.

Díaz, Frida, and Ramses Barroso. "Diseño y validación de una propuesta de evaluación auténtica de competencias en un programa de formación de docentes de educación básica en México.” Perspectiva Educacional 53, no. 1 (2014): 36-56.

Drago, Daniela, Sandra Shire, and Ozgur Ekmekci. "Improving Regulatory Education: Can We Reconcile Employers' Expectations With Academic Offerings?" Therapeutic Innovation \& Regulatory Science 50, no. 3 (2016): 330-336.

Dragoo, Amie, and Richard Barrows. "Implementing Competency-Based Education: Challenges, Strategies, and a Decision-Making Framework." The Journal of Continuing Higher Education 64, no. 2 (2016): 73-83.

Durán-García, Martin, and Emilse Durán-Aponte. "Empresa, universidad y competencias. Propuesta de un modelo sistémico.” Revista Gestión Universitaria 3, no. 3 (2011). URL http://www.gestuniv.com.ar/gu_03/v3n3a3.htm.

Elizalde, Leticia, and Rafael Reyes. "Elementos clave para la evaluación del desempeño de los docentes." Revista electrónica de investigación educativa 10 (2008): 1-8.

ENQA. "Standards and guidelines for Quality Assurance in European Higher Education Area." Helsinki, ENQA. Last modified 2005. http://www.enqa.net/bologna.lasso.

. "Standards and guidelines for Quality Assurance in European Higher Education Area.” Brussels, Belgium. Last modified 2015. http://www.enqa.eu/index.php/ home/esg/.

Fernández, María. "From the Teaching-Based Model to the Learning-Based Model: A Comparative Study." Procedia-Social and Behavioral Sciences 237 (2017): 678684.

Fernández, Amparo. "Metodologías activas para la formación de competencias." Educatio siglo XXI 24 (2006): 35-56. 
Ferro, Carlos, Ana Isabel Martínez, and María del Carmen Otero. "Ventajas del uso de las TICs en el proceso de enseñanza-aprendizaje desde la óptica de los docentes universitarios españoles." EDUTEC, Revista Electrónica de Tecnología Educativa 29 (2009): 1-12.

Fuentes, Raúl, and Lucía Amorós. "Evaluación de competencias: Un ejemplo en posgrado." Revista Electrónica de Desarrollo de Competencias (REDEC) 5, no. 1 (2012): 1-22.

García, María José. Evaluar la integración de las competencias en la universidad. Bilbao: Mensajero, 2013.

García, María Pilar. "Estatus actual del profesorado en la educación superior: revisión de conceptos y modelos competenciales." Tonos Digital 30 (2016): 1-21.

García, Rosa, Sonsoles Guerra, Natalia González, and Emilio Álvarez. "Estudio exploratorio de las percepciones del profesorado universitario respecto a la gestión de la docencia." Educación XXI 13, no 2 (2010): 163-184.

García-Ayllón, Salvador, and Antonio Tomás Espín. "La acreditación y promoción del profesorado en la universidad española: situación, tendencias y perspectivas de futuro." REDU 12, no. 4 (2014): 39-62.

García-Cabrero, Benilde, Javier Loredo, and Carranza, Guadalupe. "Análisis de la práctica educativa de los docentes: pensamiento, interacción y reflexión.” Revista Electrónica de Investigación Educativa 10 (2008): 1-15.

García-Olalla, Ana. "Estándares para evaluar la calidad docente.” In La Innovación Educativa para transformar la sociedad multicultural: El papel de las Universidades, edited by Aurelio Villa, 77-93. Bogotá: FIIU, 2014.

. "El Portafolio Docente: Un instrumento para evaluación y mejora de la práctica docente." Revista CIDUI 2 (2014b): 1-13.

García-Olalla, Ana, and Elena Auzmendi. "Evaluación de la Planificación de la docencia en las asignaturas de Grado". En Libro de Actas CIDUI 2012, La Universidad una institución de la sociedad. Last modified 2012. http://www .cidui.org/revista-cidui12

Giménez, Analia. "El papel de la gestión de centros educativos en un modelo de aprendizaje basado en competencias." Páginas de Educación 9, no. 1 (2016): 5-15.

González, Julia, and Robert Wagenaar. Tuning Educational Structures in Europe. Final Report-Phase 1. Bilbao: Universidad de Deusto, 2003.

eds. Tuning educational Structures in Europe. Universities contribution to the Bologna Process. Final Report. Pilot Project - Phase 2. Bilbao: University of Deusto and University of Groningen, 2006.

Gruppen, Larry, John Burkhardt, James Fitzgerald, Martha Funnell, Hilary Haftel, Monica Lypson, and John Vasquez. "Competency based education: programme design and challenges to implementation." Medical education 50, no. 5 (2016): 532 539.

Harris, Peter, Linda Snell, Martin Talbot, Ronald Harden, and International CBME Collaborators. "Competency-based medical education: implications for undergraduate programs." Medical Teacher 32, no. 8 (2010): 646-650.

Hernández, Robert, Carlos Fernández, and Pilar Baptista.Metodología de la investigación. México: McGraw Hill, 2014. 
Icarte, Gabriel, and Hugo Lávate. "Metodología para la revisión y actualización de un diseño curricular de una carrera universitaria incorporando conceptos de aprendizaje basado en competencias." Formación Universitaria 9, no. 2 (2016): 3-16.

Jornet, Jesús, José González, Jesús Suárez, and María Jesús Perales. "Diseños de evaluación de competencias: consideraciones acerca de los estándares en el dominio de las competencias." Bordón 63, no. 1 (2011): 125-145.

Klein-Collins, Rebecca, and Elizabeth Baylor. "Meeting Students Where They Are: Profiles of Students in Competency-Based Degree Programs.” Last modified 2012. http://www. cbenetwork.org/sites/457/uploaded/files/CAELstudentreportcorrected.pdf.

Knapp, Thomas, and Ralph Mueller. "Reliability and validity of instruments." In The reviewer guide to quantitative methods in the social sciences, edited by Gregory Hancock, and Ralph Mueller, 337-341. New York: Routledge, 2010.

Ku Mota, María Magdalena, and José Tejada. Diagnóstico de necesidades basadas en competencia del profesorado de los institutos Tecnológicos de Quintana Roo, México. Barcelona: Universitat Autònoma de Barcelona, Departament de Pedagogia Aplicada, 2013.

Lagali-Jirge, Vasanti. "Need for paradigm shift in Indian dental education: A case for change toward competency-based education." Journal of Indian Academy of Oral Medicine and Radiology 27, no. 2 (2015): 230-236.

López-Pastor, Víctor. "El papel de la evaluación formativa en el proceso de convergencia hacia el EEES: Análisis del estado de la cuestión y presentación de un sistema de intervención." Revista interuniversitaria de formación del profesorado 20, no. 3 (2006): 93-119.

. "El papel de la evaluación formativa en la evaluación por competencias: aportaciones de la red de evaluación formativa y compartida en docencia universitaria." REDU, Revista de Docencia Universitaria 9, no. 1 (2011): 159-173.

Marbán, José María, coord. Análisis de las herramientas de evaluación de la Calidad Docente mediante contrastes basados en Estándares Internacionales de Excelencia. Madrid: Ministerio de Educación, Cultura y Deporte - Proyecto EA2011-0113, 2012.

Maura, Viviana, and Rosa Tirados. "Competencias genéricas y formación profesional: un análisis desde la docencia universitaria." Revista iberoamericana de educación 47 (2008): 185-209.

MEC. "Propuesta para la Renovación de las metodologías educativas en la universidad". Madrid, MEC, Secretaría de Estado de Universidades. Last modified 2006. http:// www.unizar.es/ice/images/stories/calidad/PROPUESTA_RENOVACION.pdf

. "Real Decreto 1393/2007, de 29 de octubre, por el que se establece la ordenación de las enseñanzas universitarias oficiales.” Last modified 2007. https://www.boe.es/ boe/dias/2007/10/30/pdfs

Montoya, Juny. "Evaluar las evaluaciones: Diseño puesta a prueba de un sistema de evaluación para el mejoramiento de la docencia en unidades." Revista iberoamericana de evaluación educativa 5, no. 1 (2012): 48-58.

Moreira, Luis Miguel, and Miguel Angel Santos. "Evaluando la enseñanza en la educación superior: percepciones de docentes y discentes.” Revista Electrónica de Investigación Educativa 18, no. 3 (2016): 19-36. 
OECD. "La Definición y Selección de Competencias clave (DESECO).” Resumen ejecutivo. Last modified 2005. http://comclave.educarex.es/pluginfile.php/130/ mod_resource/content/3/DESECO.pdf

Olmos-Migueláñez, Susana, and María José Rodríguez-Conde. "El profesorado universitario ante la e-evaluación del aprendizaje.” ESE. Estudios Sobre Educación. Revista semestral del Departamento de Educación de la Facultad de Filosofía y Letras de la Universidad de Navarra 20 (2011): 181-202.

Padilla, María Teresa, and Javier Gil. "La evaluación orientada al aprendizaje en la Educación Superior: condiciones y estrategias para su aplicación en la docencia universitaria.” Revista española de pedagogía 241 (2008): 467-485.

Pallisera, María, Judit Fullana, Anna Planas, and Arantza Del Valle. "La adaptación al espacio europeo de educación superior en España: los cambios/retos que implica la enseñanza basada en competencias y orientaciones para responder a ellos." Revista Iberoamericana de Educación 52, no. 4 (2010): 1-13.

Poblete, Manuel. "Evaluación de competencias en la Educación Superior: dificultades y condiciones.” IV Jornadas Universitarias de Innovación y Calidad. Bilbao: Universidad de Deusto, 2008.

Poblete, Manuel, and Ana García-Olalla. Desarrollo de competencias y créditos transferibles. Experiencia multidisciplinar en el contexto universitario. Bilbao: Mensajero, 2007.

Poblete, Manuel, María José Bezanilla, Donna Fernández, and Lucía Campo. "Formación del docente en competencias genéricas: un instrumento para su planificación y desarrollo." Educar 52, no. 1 (2016): 71-91.

REACU. "Protocolo de evaluación para la verificación de títulos universitarios oficiales". Last modified April 6,2016. http://www.aneca.es/content/download/12387/153627/ file/verifica_protocolo_gradomaster_110207.pdf.

Rodríguez, Rosa María. "Mejora continua de la práctica docente universitaria: una experiencia desde el proceso de convergencia del EEES." Revista Electrónica Interuniversitaria de Formación del Profesorado 10, no. 1 (2007): 1-8.

Rovira, Enric. "Competencias genéricas en la formación universitaria." Revista de Educação 325 (2001): 229-321.

Rueda, Mario. "La evaluación del desempeño docente: consideraciones desde el enfoque por competencias.” Revista Electrónica de Investigación Educativa 11, no. 2 (2009): $1-16$.

Salinas, Jesús. "Innovación docente y uso de las TIC en la enseñanza universitaria." RUSC, Universities and Knowledge Society Journal 1, no. 1 (2004) 1-16.

Sanz, María Paz, and Laura Raquel Pedreño. "La planificación de evaluación de competencias en Educación Superior." Revista electrónica interuniversitaria de formación del profesorado 14, no. 1 (2011): 113-124.

Schmal, Rodolfo, and Andrés Ruiz-Tagle. "Una metodología para el diseño de un currículo orientado a las competencias." Ingeniare, Revista chilena de ingeniería 16, no. 1 (2008): 147-158. 
Schmal, Rodolfo, and Andrés Ruiz-Tagle. "Un modelo para la gestión de una escuela universitaria orientada a la formación basada en competencias." Cuadernos de Administración 22, no. 39 (2009): 287-305.

Schmal, Rodolfo, and Andrés Ruiz-Tagle. "Una metodología para el diseño de un currículo orientado a las competencias." Revista electrónica de desarrollo de competencias 2, no. 4 (2009): 1-21.

Sepúlveda, Alejandro, Margaly Andrea Quintana, Margarita Opazo, Rodolfo Lemarie, andDaniel Sáez."Nivel de promoción de competencias genéricas-sello institucionales en Educación Básica, parvularia y diferencial: percepción de los estudiantes." Revista de Orientación Educacional 27, no. 52 (2013): 75-87.

Serpa, Gerardo, Adriana Falcón, and Elvia Isabel Echeverría. "Contribución de los metaperfiles a mejorar la formación por competencias: el caso de la carrera de Enfermería en Uniandes." Revista de Ciencia, Tecnología e Innovación 3, no. 2 (2016): 1-16.

Stufflebeam, Daniel. "The CIPP Model for program evaluation”. In Evaluation models, edited by George Madaus, Michael Scriven, and Daniel Stufflebeam. Boston: Kluwer-Nijhoff, 1983.

Stufflebeam, Daniel, and Anthony Shinkfield. Evaluation theory, models and applications. San Francisco: Jossey-Bass, 2007.

Tejada, José. “Competencias Docentes." Profesorado, Revista de curriculum y formación del profesorado 13, no. 2 (2009): 1-15.

Tejedor, Francisco Javier, and Ana García-Valcárcel. "Causas del bajo rendimiento del estudiante universitario (en opinión de los profesores y alumnos). Propuesta de mejora en el marco del EEES.” Revista de Educación 342 (2007): 443- 472.

Torrecilla, Eva María, María José Rodríguez, María Esperanza Herrera, and Juan Francisco Martín. "Evaluación de calidad de un proceso de tutoría de titulación universitaria: la perspectiva del estudiante de nuevo ingreso en educación." REOP, Revista Española de Orientación y Psicopedagogía 24, no. 2 (2013): 79-99.

Universidad de Deusto. Marco Pedagógico de la Universidad de Deusto. Bilbao: UD, 2001.

.Pautas para la elaboración del Perfil Académico - Profesional de la Titulación. Bilbao: UD, 2003.

. Orientaciones para la formulación y el desarrollo de competencias específicas. Bilbao: UD, 2007a.

. Normas y Orientaciones para la Elaboración de Programas y Guías de Aprendizaje. Bilbao: UD, 2007b.

. Manual para la Garantía Interna de Calidad Docente: Modelo de desarrollo profesional en la UD. Bilbao: UD, 2007c.

Valcarcel, Miguel, coord. La preparación del profesorado universitario para la convergencia europea en educación superior. Madrid: Informe Investigación, Proyecto EA2003-0040, 2005.

Villa, Aurelio, and Ana García-Olalla. "Un sistema de garantía de calidad de la docencia: un estudio de caso." Revista Electrónica Interuniversitaria de Formación del Profesorado 17, no. 3 (2014): 65-78. 
Villa, Aurelio, and Manuel Poblete. Competence-based learning. A proposal for the assessment of generic competences. Bilbao: University of Deusto, 2009.

Villa, Aurelio, and Manuel Poblete. "Evaluación de competencias genéricas: principios, oportunidades y limitaciones." Bordón 63, no. 1 (2011): 147-170.

Villa, Aurelio, Sonia Arranz, Lucía Campo, and Olga Villa,. "Percepción del profesorado y responsables académicos sobre el proceso de implantación del Espacio Europeo de Educación Superior en diversas titulaciones de educación." Profesorado, Revista de currículum y formación del profesorado 19, no. 2 (2015): 245-264.

Villa, Aurelio, Lucía Campo, Olga Villa, Ana García-Olalla, and Sonia Arranz. "Valoración del profesorado de magisterio sobre el aprendizaje basado en competencias implantado." Profesorado, Revista de currículum y formación del profesorado 17, no. 3 (2013): 35-55.

Villardón, María Lourdes. "Evaluación del aprendizaje para promover el desarrollo de competencias." Educatio siglo XXI 24 (2006): 57-76.

Villarroel, Verónica, and Daniela Bruna. "Reflexiones en torno a las competencias genéricas en educación superior: Un desafío pendiente." Psicoperspectivas 13, no. 1 (2014): 23-34.

Zabalza, Miguel Ángel. Competencias docentes del profesorado universitario. Calidady desarrollo profesional. Madrid: Narcea, 2003.

\section{Tables}

\section{Table 1}

Dimension 1 - Criteria and indicators

\begin{tabular}{|l|l|}
\hline \multicolumn{1}{|c|}{ Criteria } & \multicolumn{1}{c|}{ Dimension 1: Legal and administrative context } \\
\hline $\begin{array}{l}\text { 1.1. There is } \\
\text { some legislation } \\
\text { in place that } \\
\text { promotes Higher } \\
\text { Education } \\
\text { innovation and } \\
\text { incorporates }\end{array}$ & $\begin{array}{l}\text { 1.1.1. The need to promote a change in Higher Education focused } \\
\text { on CBL is justified. }\end{array}$ \\
\cline { 2 - 2 } $\begin{array}{l}\text { Competence- } \\
\text { Based Learning } \\
\text { (CBL) and/or } \\
\text { student-centred } \\
\text { learning. }\end{array}$ & $\begin{array}{l}\text { 1.1.2. The innovation process is based on student-centred } \\
\text { learning. }\end{array}$ \\
\cline { 2 - 3 } \begin{tabular}{l} 
emphasised. \\
\cline { 2 - 3 }
\end{tabular} & $\begin{array}{l}\text { 1.1.5. Higher Education cycles are harmonised and recognised. } \\
\text { This is regulated on the basis of competences (bachelor, master } \\
\text { and doctorate) (framework for degrees/qualifications). }\end{array}$ \\
\hline
\end{tabular}




\begin{tabular}{|c|c|}
\hline \multicolumn{2}{|r|}{ Dimension 1: Legal and administrative context } \\
\hline Criteria & Indicators \\
\hline \multirow{5}{*}{$\begin{array}{l}1.2 . \text { There } \\
\text { is guiding } \\
\text { legislation on } \\
\text { how to develop } \\
\text { a competence- } \\
\text { based degree. }\end{array}$} & $\begin{array}{l}\text { 1.2.1. It is specified that learning objectives must be formulated in } \\
\text { terms of competences. }\end{array}$ \\
\hline & $\begin{array}{l}\text { 1.2.2. Generic (transversal or key) competences and degree- } \\
\text { specific competences are differentiated. }\end{array}$ \\
\hline & $\begin{array}{l}\text { 1.2.3. The importance of student-centred methodologies is } \\
\text { specified. }\end{array}$ \\
\hline & $\begin{array}{l}\text { 1.2.4. The need to define student workload and work time is } \\
\text { established. This translates into a credit system. }\end{array}$ \\
\hline & $\begin{array}{l}\text { 1.2.5. The need to use competence-based assessment is specifically } \\
\text { stated. }\end{array}$ \\
\hline \multirow{2}{*}{$\begin{array}{l}\text { 1.3. Higher } \\
\text { Education } \\
\text { institutions } \\
\text { and Education } \\
\text { Authorities } \\
\text { or delegated } \\
\text { agencies/ } \\
\text { organisations } \\
\text { have put in place } \\
\text { mechanisms } \\
\text { or procedures } \\
\text { to certify and } \\
\text { supervise degrees, } \\
\text { including } \\
\text { references to CBL. }\end{array}$} & $\begin{array}{l}\text { 1.3.1. There are external official mechanisms for certification } \\
\text { and improvement at university, degree and teaching levels put } \\
\text { in place by the Education Authorities or delegated agencies/ } \\
\text { organisations. }\end{array}$ \\
\hline & $\begin{array}{l}\text { 1.3.2. There is a demand for an internal system for quality } \\
\text { assurance and improvement at university, degree and/or teaching- } \\
\text { learning levels. }\end{array}$ \\
\hline \multirow{4}{*}{$\begin{array}{l}\text { 1.4. There is } \\
\text { governmental } \\
\text { support available } \\
\text { (financing, } \\
\text { training, teaching } \\
\text { innovation and } \\
\text { improvement, } \\
\text { incentive } \\
\text { programmes...) } \\
\text { for implementing } \\
\text { CBL. }\end{array}$} & $\begin{array}{l}\text { 1.4.1. Funding is made available for teaching staff training in } \\
\text { connection with } \mathrm{CBL} \text { implementation. }\end{array}$ \\
\hline & $\begin{array}{l}\text { 1.4.2. Funding is made available for projects for the design and } \\
\text { introduction of competence-based degrees. }\end{array}$ \\
\hline & $\begin{array}{l}\text { 1.4.3. Funding is made available and incentives are provided for } \\
\text { research projects and/or university teaching innovation for } \mathrm{CBL} \\
\text { implementation. }\end{array}$ \\
\hline & $\begin{array}{l}\text { 1.4.4. Funding is made available for the human and material } \\
\text { resources necessary to implement the changes involved in CBL. }\end{array}$ \\
\hline
\end{tabular}


Table 2

Dimension 2 - Criteria and indicators

\begin{tabular}{|c|c|}
\hline \multicolumn{2}{|r|}{ Dimension 2: Institutional context } \\
\hline Criteria & Indicators \\
\hline \multirow{4}{*}{$\begin{array}{l}\text { 2.1. CBL is } \\
\text { included in } \\
\text { institutional } \\
\text { documents (policy } \\
\text { and strategy } \\
\text { and pedagogical } \\
\text { model). }\end{array}$} & $\begin{array}{l}\text { 2.1.1. Reference is made to } \mathrm{CBL} \text { in the mission, vision and strategic } \\
\text { plan. }\end{array}$ \\
\hline & $\begin{array}{l}\text { 2.1.2. The university has a teaching and/or training model that } \\
\text { includes CBL. }\end{array}$ \\
\hline & $\begin{array}{l}\text { 2.1.3. The university defines a number of key competences to be } \\
\text { acquired by students. }\end{array}$ \\
\hline & $\begin{array}{l}\text { 2.1.4. Institutional documents referring to CBL are publicly shown } \\
\text { on the university's website. }\end{array}$ \\
\hline \multirow{4}{*}{$\begin{array}{l}\text { 2.2. There is } \\
\text { support for } \\
\text { CBL from the } \\
\text { organisational } \\
\text { structure. }\end{array}$} & $\begin{array}{l}\text { 2.2.1. There must be at least one person responsible for } C B L \\
\text { implementation in the Vice-Chancellor's/governing team. }\end{array}$ \\
\hline & $\begin{array}{l}\text { 2.2.2. At institutional level, there is a technical office/unit that } \\
\text { promotes and provides support for CBL. }\end{array}$ \\
\hline & $\begin{array}{l}\text { 2.2.3. The centres/faculties have a structure to bolster and } \\
\text { organise CBL. }\end{array}$ \\
\hline & 2.2.4. Administrative processes and services are in line with CBL. \\
\hline \multirow{4}{*}{$\begin{array}{l}\text { 2.3. There are } \\
\text { guidelines for } \\
\text { developing } \\
\text { mechanisms } \\
\text { for the design, } \\
\text { approval and } \\
\text { supervision of } \\
\text { competence- } \\
\text { based degrees } \\
\text { and teaching } \\
\text { guides. }\end{array}$} & $\begin{array}{l}\text { 2.3.1. The institution has formal mechanisms (procedures and } \\
\text { protocols) in place for the development of competence-based } \\
\text { degrees. }\end{array}$ \\
\hline & $\begin{array}{l}\text { 2.3.2. The institution has formal mechanisms (procedures and } \\
\text { protocols) in place for the approval, monitoring and periodic } \\
\text { review of competence-based degrees. }\end{array}$ \\
\hline & $\begin{array}{l}\text { 2.3.3. The institution has formal mechanisms (procedures and } \\
\text { protocols) in place for the development of competence-based } \\
\text { programmes and teaching guides. }\end{array}$ \\
\hline & $\begin{array}{l}\text { 2.3.4. The institution has formal mechanisms (procedures and } \\
\text { protocols) in place for the approval, monitoring and periodic } \\
\text { review of competence-based programmes and teaching guides. }\end{array}$ \\
\hline
\end{tabular}




\begin{tabular}{|c|c|}
\hline \multicolumn{2}{|r|}{ Dimension 2: Institutional context } \\
\hline Criteria & Indicators \\
\hline \multirow{7}{*}{$\begin{array}{l}\text { 2.4. There are } \\
\text { procedures for } \\
\text { the selection, } \\
\text { development, } \\
\text { assessment and/ } \\
\text { or certification } \\
\text { of teaching and } \\
\text { administrative } \\
\text { and services staff. }\end{array}$} & $\begin{array}{l}\text { 2.4.1. There are competence-based procedures for the selection, } \\
\text { development, assessment and certification of teaching staff. }\end{array}$ \\
\hline & $\begin{array}{l}\text { 2.4.2. Informative and work meetings/awareness workshops/ } \\
\text { courses are held on CBL. }\end{array}$ \\
\hline & $\begin{array}{l}\text { 2.4.3. The university has devised some mechanisms to detect } \\
\text { teaching staff needs for the adequate development and } \\
\text { improvement of its degrees. }\end{array}$ \\
\hline & $\begin{array}{l}\text { 2.4.4. The university has mechanisms to detect administrative } \\
\text { and services staff needs for the adequate development and } \\
\text { improvement of its degrees. }\end{array}$ \\
\hline & $\begin{array}{l}\text { 2.4.5. The university promotes and supports faculty members' } \\
\text { involvement in innovation and/or research informed by CBL. }\end{array}$ \\
\hline & $\begin{array}{l}\text { 2.4.6. The university offers training to its teaching staff with a } \\
\text { view to carrying out any improvements identified to be necessary } \\
\text { for adequate CBL implementation. }\end{array}$ \\
\hline & $\begin{array}{l}\text { 2.4.7. The university offers training to its administrative and } \\
\text { services staff with a view to carrying out any improvements } \\
\text { identified to be necessary for adequate CBL implementation. }\end{array}$ \\
\hline
\end{tabular}


Table 3

Dimension 3 - Criteria and indicators

\begin{tabular}{|c|c|}
\hline \multicolumn{2}{|r|}{ Dimension 3: Degree planning process } \\
\hline Criteria & Indicators \\
\hline \multirow{10}{*}{$\begin{array}{l}\text { 3.1. There is a } \\
\text { curriculum that } \\
\text { defines the } \\
\text { competences to } \\
\text { be acquired in } \\
\text { the degree and } \\
\text { explicitly states } \\
\text { how certain } \\
\text { competences are } \\
\text { acquired within a } \\
\text { given subject (or } \\
\text { other equivalent } \\
\text { unit). }\end{array}$} & $\begin{array}{l}\text { 3.1.1. There is an individual or a commission responsible for the } \\
\text { process of development, coordination, monitoring and assessment } \\
\text { of the degree programme. }\end{array}$ \\
\hline & $\begin{array}{l}\text { 3.1.2. A degree's purpose and direction is based on a systematic } \\
\text { analysis of the background information and the needs and } \\
\text { proposals provided by the different stakeholders: academics, } \\
\text { students, graduates, employers and other agents involved. }\end{array}$ \\
\hline & $\begin{array}{l}\text { 3.1.3. The professional-academic profile of the degree has been } \\
\text { defined. This includes establishing a professional identity, the } \\
\text { roles for which it is intended and the areas where professional } \\
\text { performance will occur. }\end{array}$ \\
\hline & $\begin{array}{l}\text { 3.1.4. The learning objectives of the degree are defined in terms } \\
\text { of the competences students will acquire while working towards } \\
\text { it. }\end{array}$ \\
\hline & $\begin{array}{l}\text { 3.1.5. The degree explicitly differentiates between generic } \\
\text { competences and specific competences to be worked on. }\end{array}$ \\
\hline & $\begin{array}{l}\text { 3.1.6. The degree programme establishes how teaching is to be } \\
\text { organised (by subjects or other equivalent units) and identifies } \\
\text { each of its constituent units. A certain workload is stipulated to be } \\
\text { carried out, inside and outside class (e.g. credits) }\end{array}$ \\
\hline & $\begin{array}{l}\text { 3.1.7. There is a competence map (or equivalent procedure) which } \\
\text { outlines the competences to be acquired within each subject } \\
\text { (or other academic units that the degree is structured into). This } \\
\text { shows that it is an integrated formative/educational project. }\end{array}$ \\
\hline & $\begin{array}{l}\text { 3.1.8. The degree programme establishes the use of active } \\
\text { methodologies that place the student at the centre of the } \\
\text { learning process, and are in accordance with the type of } \\
\text { competences to be acquired. }\end{array}$ \\
\hline & $\begin{array}{l}\text { 3.1.9. The degree programme establishes the use of methods } \\
\text { and techniques that assess the extent to which the competences } \\
\text { described have been achieved, both throughout the learning } \\
\text { process and in terms of final outcomes. }\end{array}$ \\
\hline & $\begin{array}{l}\text { 3.1.10. The degree programme provides a mechanism to establish } \\
\text { the extent to which the relevant competences have been } \\
\text { acquired. This operates on a coordinated, collegial basis. }\end{array}$ \\
\hline
\end{tabular}




\begin{tabular}{|c|c|}
\hline \multicolumn{2}{|r|}{ Dimension 3: Degree planning process } \\
\hline Criteria & Indicators \\
\hline \multirow{7}{*}{$\begin{array}{l}\text { 3.2. Faculty } \\
\text { members involved } \\
\text { in the delivery } \\
\text { of the degree } \\
\text { programme } \\
\text { define how } \\
\text { competences will } \\
\text { be achieved in } \\
\text { their respective } \\
\text { subjects (or } \\
\text { equivalent units). } \\
\text { They do so by } \\
\text { engaging in joint } \\
\text { procedures and } \\
\text { decisions. }\end{array}$} & $\begin{array}{l}\text { 3.2.1. The individual responsible for the degree programme } \\
\text { establishes and/or puts in place the necessary mechanisms } \\
\text { (meetings, documentation) to ensure the coordinated planning } \\
\text { of the degree, through an integrated approach of the subjects (or } \\
\text { equivalent units) within it. }\end{array}$ \\
\hline & $\begin{array}{l}\text { 3.2.2. The faculty and other individuals responsible for degree } \\
\text { design and implementation agree on and define how the various } \\
\text { competences should be included in each of the subjects/modules. }\end{array}$ \\
\hline & $\begin{array}{l}\text { 3.2.3. The teaching-learning and assessment methodologies to be } \\
\text { used in the subjects (or equivalent units) are discussed and agreed } \\
\text { upon in order to diversify and coordinate the learning scenarios } \\
\text { proposed to students. }\end{array}$ \\
\hline & $\begin{array}{l}\text { 3.2.4. Learning and/or assessment activities are planned on a } \\
\text { joint basis for different subjects, in order to promote an overall, } \\
\text { integrated acquisition of the competences. }\end{array}$ \\
\hline & $\begin{array}{l}\text { 3.2.5. Distribution of student workload among each of the } \\
\text { subjects is discussed with a view to favouring continued balanced } \\
\text { work. }\end{array}$ \\
\hline & $\begin{array}{l}\text { 3.2.6. Assessment of the extent to which the degree's } \\
\text { competences are achieved is carried out on a coordinated and } \\
\text { transversal basis (horizontal and/or vertical). }\end{array}$ \\
\hline & $\begin{array}{l}\text { 3.2.7. A record is kept of the decisions taken with regard to } \\
\text { degree coordination. }\end{array}$ \\
\hline
\end{tabular}


Table 4

Dimension 4 - Criteria and indicators

\begin{tabular}{|c|c|}
\hline \multicolumn{2}{|r|}{ Dimension 4: Subject/Module planning process } \\
\hline Criteria & Indicators \\
\hline \multirow{4}{*}{$\begin{array}{l}\text { 4.1. The } \\
\text { contribution of } \\
\text { the subject to the } \\
\text { graduate profile } \\
\text { is described and } \\
\text { competences are } \\
\text { specified. }\end{array}$} & $\begin{array}{l}\text { 4.1.1. The lecturer contextualises and describes the purpose } \\
\text { for the subject (or equivalent unit) and its contribution to the } \\
\text { academic-professional graduate profile. }\end{array}$ \\
\hline & $\begin{array}{l}\text { 4.1.2. The lecturer clearly sets out the prerequisites for students } \\
\text { and the relationship between their module and the other } \\
\text { modules in the degree. }\end{array}$ \\
\hline & $\begin{array}{l}\text { 4.1.3. The programme and/or study guide establishes the generic } \\
\text { competences to be acquired within a given subject in accordance } \\
\text { with the competence map, and specify the aspects to be worked } \\
\text { on. }\end{array}$ \\
\hline & $\begin{array}{l}\text { 4.1.4. The programme and/or study guide define the specific } \\
\text { competences to be acquired within the subject, in accordance } \\
\text { with the competence map, and specify the aspects to be worked } \\
\text { on. }\end{array}$ \\
\hline \multirow{4}{*}{$\begin{array}{l}\text { 4.2. Appropriate } \\
\text { teaching-learning } \\
\text { strategies for the } \\
\text { acquisition of } \\
\text { competences are } \\
\text { detailed. }\end{array}$} & $\begin{array}{l}\text { 4.2.1. Lecturers design a teaching strategy that is coherent } \\
\text { with the competences students need to work on, and with the } \\
\text { principles of autonomy and meaningful learning. }\end{array}$ \\
\hline & $\begin{array}{l}\text { 4.2.2. Lecturers detail the activities to be carried out and } \\
\text { the estimated time for completion, according to the principles } \\
\text { of autonomy and meaningful learning. The overall workload/ } \\
\text { time assigned to each subject/module (or assigned credits where } \\
\text { applicable) needs to be respected. }\end{array}$ \\
\hline & $\begin{array}{l}\text { 4.2.3. Lecturers provide a detail explanation of the } \\
\text { documentation and support resources to be used for the proper } \\
\text { monitoring of the subject/module and completion of the activities } \\
\text { included in the programme. }\end{array}$ \\
\hline & $\begin{array}{l}\text { 4.2.4. Lecturers establish the procedures, schedules and spaces } \\
\text { to monitor, tutor, and guide student learning. }\end{array}$ \\
\hline
\end{tabular}




\begin{tabular}{|l|l|}
\hline \multicolumn{1}{|c|}{ Criteria } & \multicolumn{1}{|c|}{ Dimension 4: Subject/Module planning process } \\
\hline $\begin{array}{l}\text { 4.3. An } \\
\text { assessment system } \\
\text { is developed that } \\
\text { is appropriate to } \\
\text { the competences } \\
\text { students are }\end{array}$ & $\begin{array}{l}\text { 4.3.1. Lecturers formulate the learning outcomes and/or indicators } \\
\text { that will be used to assess and provide feedback to students on } \\
\text { the extent to which they have acquired their competences. }\end{array}$ \\
\cline { 2 - 2 } $\begin{array}{l}\text { (formative and } \\
\text { summative } \\
\text { assessment). }\end{array}$ & $\begin{array}{l}\text { 4.3.2. Lecturers choose the techniques and instruments to be used } \\
\text { to gather the information relevant to the learning outcomes and/ } \\
\text { or selected indicators, both throughout and at the end of the } \\
\text { process. }\end{array}$ \\
\cline { 2 - 2 } & $\begin{array}{l}\text { 4.3.3. Lecturers provide detailed information about the marking } \\
\text { scheme (the weighting of each competence/indicator towards the } \\
\text { final mark), which reflects the extent to which the competences } \\
\text { have been acquired, both throughout the process and upon } \\
\text { completion of the module programme. }\end{array}$ \\
\hline
\end{tabular}

\section{Table 5}

\section{Dimension 5 - Criteria and indicators}

\begin{tabular}{|c|c|}
\hline \multicolumn{2}{|r|}{ Dimension 5: Teaching/learning practices and assessment } \\
\hline Criteria & Indicators \\
\hline \multirow{8}{*}{$\begin{array}{l}\text { 5.1. Active } \\
\text { methodologies } \\
\text { and appropriate } \\
\text { resources } \\
\text { (resources, } \\
\text { ICT, activities, } \\
\text { spaces) are used } \\
\text { to ensure the } \\
\text { competences for } \\
\text { the module can } \\
\text { be achieved. }\end{array}$} & $\begin{array}{l}\text { 5.1.1. The teaching conditions for the delivery of the modules } \\
\text { (number of students, spaces, classrooms) are appropriate to the } \\
\text { type of module and the competences to be acquired. }\end{array}$ \\
\hline & $\begin{array}{l}\text { 5.1.2. The lecturer informs students of the generic and specific } \\
\text { competences to be worked towards in the module/subject, the } \\
\text { methodologies to be used and how competences are to be } \\
\text { assessed. }\end{array}$ \\
\hline & $\begin{array}{l}\text { 5.1.3. The methodologies used are coherent with the competences } \\
\text { to be worked on within the modules. }\end{array}$ \\
\hline & $\begin{array}{l}\text { 5.1.4. The methodologies encourage students to take an active } \\
\text { role in their teaching/learning process. }\end{array}$ \\
\hline & $\begin{array}{l}\text { 5.1.5. Varied methodologies (PBL, cooperative learning, case } \\
\text { studies) and/or different techniques (simulation, debates, } \\
\text { competitions, role-playing) are used. }\end{array}$ \\
\hline & $\begin{array}{l}\text { 5.1.6. Proposed activities are contextualised and real (they are } \\
\text { authentic tasks). }\end{array}$ \\
\hline & 5.1.7. ICT is used to support the teaching/learning process. \\
\hline & $\begin{array}{l}\text { 5.1.8. Teaching resources are adapted to the teaching/learning } \\
\text { methodologies. }\end{array}$ \\
\hline
\end{tabular}




\begin{tabular}{|c|c|}
\hline \multicolumn{2}{|r|}{ Dimension 5: Teaching/learning practices and assessment } \\
\hline Criteria & Indicators \\
\hline \multirow{2}{*}{$\begin{array}{l}\text { 5.2. The lecturer } \\
\text { uses tutorials } \\
\text { to guide and } \\
\text { support the } \\
\text { teaching/learning } \\
\text { process. }\end{array}$} & $\begin{array}{l}\text { 5.2.1. Lecturers guide and support students throughout the } \\
\text { teaching/learning process. }\end{array}$ \\
\hline & $\begin{array}{l}\text { 5.2.2. Both teaching-learning oriented tutorials (intended to } \\
\text { monitor the modules) and guidance tutorials (to provide personal } \\
\text { and professional advice) are integrated in order to ensure that the } \\
\text { module is appropriately delivered. }\end{array}$ \\
\hline \multirow{9}{*}{$\begin{array}{l}\text { 5.3. Acquisition } \\
\text { of competences } \\
\text { by students is } \\
\text { assessed by using } \\
\text { appropriate } \\
\text { criteria and } \\
\text { techniques. }\end{array}$} & $\begin{array}{l}\text { 5.3.1. Assessment is coherent with the competences to be worked } \\
\text { on within the modules. }\end{array}$ \\
\hline & 5.3.2. Both generic and subject-specific competences are assessed. \\
\hline & 5.3.3 A variety of assessment techniques and instruments are used. \\
\hline & $\begin{array}{l}\text { 5.3.4. The assessment process is transparent: students know the } \\
\text { instruments, criteria, indicators and weightings involved. }\end{array}$ \\
\hline & $\begin{array}{l}\text { 5.3.5. There is formative assessment, which helps students to } \\
\text { adjust their learning according to the feedback received. }\end{array}$ \\
\hline & $\begin{array}{l}\text { 5.3.6. Students know when formative and summative assessment } \\
\text { is used. }\end{array}$ \\
\hline & $\begin{array}{l}\text { 5.3.7. Students receive quantitative and qualitative feedback on } \\
\text { their work. }\end{array}$ \\
\hline & 5.3.8. ICT is used to support the assessment process. \\
\hline & $\begin{array}{l}\text { 5.3.9. Different agents participate in the assessment process: } \\
\text { lecturers (module leaders), their colleagues and students. }\end{array}$ \\
\hline
\end{tabular}




\section{Table 6}

Dimension 6 - Criteria and indicators

\begin{tabular}{|l|l|}
\hline \multicolumn{2}{|c|}{ Dimension 6: Subject/Module review and improvement } \\
\hline \multicolumn{1}{|c|}{$\begin{array}{l}\text { 6.1 Lecturers } \\
\text { analyse teaching } \\
\text { and learning } \\
\text { outcomes, and } \\
\text { propose and } \\
\text { take actions for } \\
\text { improvement. }\end{array}$} & $\begin{array}{l}\text { 6.1.1. Lecturers reflect on their teaching practices by analysing the } \\
\text { relationship between the extent to which the competences have } \\
\text { been acquired by their students and the teaching and assessment } \\
\text { methods used. }\end{array}$ \\
\cline { 2 - 2 } & $\begin{array}{l}\text { 6.1.2. Lecturers reflect on the assessment by relying on different } \\
\text { sources involved in their teaching process: students, colleagues, } \\
\text { managers and their own experience. }\end{array}$ \\
\cline { 2 - 3 } & $\begin{array}{l}\text { 6.1.3. Lecturers identify the strengths and weaknesses in their } \\
\text { teaching. }\end{array}$ \\
\cline { 2 - 2 } & $\begin{array}{l}\text { 6.1.4. Lecturers identify specific changes and changes for students } \\
\text { to improve their competence-based learning for the following } \\
\text { year. }\end{array}$ \\
\cline { 2 - 2 } & $\begin{array}{l}\text { 6.1.5. Lecturers document their reflections and discuss them with } \\
\text { their line managers or within their department. }\end{array}$ \\
\hline
\end{tabular}


Table 7

Dimension 7 - Criteria and indicators

\begin{tabular}{|l|l|}
\hline \multicolumn{1}{|c|}{ Criteria } & \multicolumn{1}{|c|}{ Indicators } \\
\hline $\begin{array}{l}\text { 7.1 There are } \\
\text { mechanisms for } \\
\text { degree review } \\
\text { and improvement }\end{array}$ & $\begin{array}{l}\text { 7.1.1 There are relevant mechanisms for gathering student } \\
\text { feedback/assessment in order to identify the areas that need } \\
\text { improvement and innovation at degree level (referring to } \\
\text { graduate profile). }\end{array}$ \\
\hline & $\begin{array}{l}\text { 7.1.2 There are relevant mechanisms for gathering graduate } \\
\text { feedback/assessment in order to identify the areas that need } \\
\text { improvement and innovation at degree level (referring to } \\
\text { graduate profile). }\end{array}$ \\
\hline \multirow{5}{*}{$\begin{array}{l}\text { 7.1.3 There are relevant mechanisms for gathering employer } \\
\text { feedback/assessment in order to identify the areas that need } \\
\text { improvement and innovation at degree level (referring to the } \\
\text { graduate profile). }\end{array}$} \\
\hline $\begin{array}{l}\text { 7.1.4 There are mechanisms for lecturers to continuously monitor } \\
\text { whether their module/subject makes a suitable contribution to } \\
\text { the attainment of the competences to work towards in relation } \\
\text { to the graduate profile. }\end{array}$ \\
\hline $\begin{array}{l}\text { 7.1.5 The review and improvement of the degree programme is } \\
\text { carried out continuously among the teaching staff on a collegial } \\
\text { basis, by looking at aspects to improve, and relying on the } \\
\text { feedback received from other stakeholders (students, graduates, } \\
\text { employers). }\end{array}$ \\
$\begin{array}{l}\text { 7.1.6 Improvement plans are drawn up that include the changes } \\
\text { identified to be necessary. }\end{array}$ \\
\hline $\begin{array}{l}\text { 7.1.7 There are flexible processes enabling the inclusion of the } \\
\text { improvements identified in the review reports ('in real time' and } \\
\text { 'without external approval'). }\end{array}$ \\
\hline $\begin{array}{l}\text { 7.1.8 The process for the implementation of improvement plans } \\
\text { is monitored/followed up. }\end{array}$ \\
$\begin{array}{l}\text { 7.1.9 The person/body in charge of improvement monitoring/ } \\
\text { follow-up is different from the one responsible for planning the } \\
\text { improvement itself. }\end{array}$ \\
\hline
\end{tabular}




\section{About the authors}

MARÍA JOSÉ BEZANILLA (marijose.bezanilla@deusto.es) holds a PhD in Education from the Institute of Education, University of London (UK) and is a tenured Lecturer at the Department of Innovation and Educational Organisation, University of Deusto (Spain). She is currently the coordinator of the doctoral programme in Education in the Faculty of Psychology and Education. As a member of the eDucaR research team, she has participated in research projects and has numerous publications on the use of information and communications technologies (ICT) and the development of competencies in higher education. In addition, she develops management and training activities at the Teaching Innovation Unit, with particular emphasis on Research and Pedagogy-ICT. Her teaching is focused on the degree in Primary Education.

ANA MARÍA GARCÍA OLALLA (ana.garciaolalla@deusto.es) holds a PhD in Pedagogy from the University of Deusto (Spain). She is a tenured Lecturer at the Faculty of Psychology and Education at the University of Deusto, where her teaching is focused on the degrees in Primary Education and Social Education and on the Master's in School Management and Administration. She is currently the Head of the Department of Innovation and Organisation in Education and is responsible for the evaluation and quality of teaching at the Teaching Innovation Unit. Her research deals with management and leadership, competencies, innovation in higher education, teaching quality, teachers' professional development and competencies.

JESSICA PAÑOS CASTRO (jessicapanos@deusto.es) holds a degree in Business Management and Administration, is a graduate in Primary Education and has a Master's degree in Development and Management of Educational and Methodological Innovation projects in educational institutions. She is currently $\mathrm{PhD}$ in Education student at the University of Deusto (Spain). She works at the University of Deusto as Licensed in charge. Her teaching is focused on the degrees in Primary Education, Physical activity and sports sciences and Social Education and Social Work. Her lines of research are focused on entrepreneurship, active methodologies and competency-based education.

MANUEL POBLETE RUIZ (manuel.poblete@deusto.es) has a PhD in Psychology at the University of Barcelona (Spain). He holds a degree in Philosophy and Literature at the Complutense University. In the private company he served as social director and consultant. In the last twelve years, in addition to the teaching work at the University of Deusto, he has participated as a coordinator and as a member of several research projects on competence development and teaching innovation. He has participated, as a speaker, in national and international congresses. He has also provided technical and training assistance to some Spanish and Latin American universities. He is currently Professor Emeritus at the University of Deusto (Spain). 


\title{
A model for the evaluation of competence-based learning implementation in higher education institutions: Criteria and indicators
}

\author{
María José Bezanilla, Ana María García Olalla, \\ Jessica Paños Castro, and Manuel Poblete Ruiz
}

doi: http://dx.doi.org/10.18543/tjhe-6(2)-2019pp127-174

\begin{abstract}
Copyright
Copyright for this article is retained by the Publisher. It is an Open Access material that is free for full online access, download, storage, distribution, and or reuse in any medium only for noncommercial purposes and in compliance with any applicable copyright legislation, without prior permission from the Publisher or the author(s). In any case, proper acknowledgement of the original publication source must be made and any changes to the original work must be indicated clearly and in a manner that does not suggest the author's and or Publisher's endorsement whatsoever. Any other use of its content in any medium or format, now known or developed in the future, requires prior written permission of the copyright holder.
\end{abstract}

